\title{
Reconstructing the Little Ice Age extent of Langfjordjøkelen, Arctic mainland Norway, as a baseline for assessing centennial-scale icefield recession
}

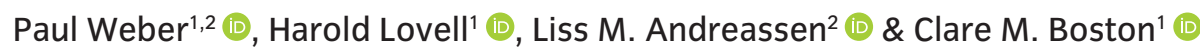 \\ 'School of the Environment, Geography and Geosciences, University of Portsmouth, Portsmouth, UK; \\ ${ }^{2}$ Norwegian Water Resources and Energy Directorate, Oslo, Norway
}

\begin{abstract}
Current warming in the Arctic is occurring at a rate two to three times higher than that of the rest of the world, leading to rapid glacier wastage. In Arctic mainland Norway, the plateau icefield Langfjordjøkelen has experienced the greatest mass loss of all Norwegian glaciers (excluding Svalbard) in recent decades. In this article, we examine this decline in a centennial-scale context through geomorphological mapping and the analysis of historical aerial photographs and maps. This allows Langfjordjøkelen's maximum Little Ice Age extent (ca. 1925) to be reconstructed, providing an important baseline for a long-term assessment of icefield change. At the LIA maximum, Langfjordjøkelen covered an area of $14.9 \mathrm{~km}^{2}$. A comparison of the LIA dimensions with the icefield extent in 1891/1902, as displayed on a historical map, reveals a substantial overestimation of the map-based glacier outline. The post-LIA evolution of Langfjordjøkelen has been characterized by sustained high rates of glacier recession. By 2018 , the icefield had lost $57 \%\left(8.5 \mathrm{~km}^{2}\right)$ of its original LIA area, at a decadal rate of $9 \%$, and its outlet glaciers had reduced in average length by $42 \%$ ( $1 \mathrm{~km}$ ), at an annual rate of $11 \mathrm{~m}$. Langfjordjøkelen's percentage area decline has been greater than that of Norwegian ice masses at lower latitudes where comparable long-term glacier change data are available. This indicates that there is a significant latitudinal variation in Norwegian glacier response to 20th century warming, likely influenced by an enhanced warming signal in Arctic Norway compared to the rest of the Norwegian mainland.
\end{abstract}

\section{Keywords}

Glacier change; glacier reconstruction; glacial geomorphology; historical maps; plateau icefield

\section{Correspondence}

Paul Weber, School of the Environment, Geography and Geosciences, University of Portsmouth, Buckingham Building, Lion Terrace, Portsmouth, PO1 3HE, UK. E-mail: paul.weber@myport.ac.uk

Abbreviations
AAR: accumulation-area ratio
$a^{-1}$ : per year
ETCW: Early 20th Century Warming
GIS: geographic information system
ID: identification
IPCC: Intergovernmental Panel on Climate
Change
LIA: Little Ice Age
NVE: Norwegian Water Resources and
Energy Directorate
RAF: Royal Air Force (UK)
W.e.: water equivalent
WMO: World Meteorological Organization

\section{Abbreviations}

ccumulation-area ratio ID: identification Change

LIA: Little Ice Age Energy Directorate w.e.: water equivalent WMO: World Meteorological Organization

\section{Introduction}

Since the pre-industrial era (1850-1900), the global mean annual temperature has risen by about $1{ }^{\circ} \mathrm{C}$ (Allen et al. 2018; WMO 2019), causing rapid glacier recession accompanied by a rise in sea level (e.g., Vaughan et al. 2013; Zemp et al. 2015; Zemp et al. 2019). This warming is amplified in the Arctic, largely because of a reduction in sea-ice cover and resulting feedback effects (Serreze et al. 2009). Here, air temperatures are currently rising at two to three times the global rate (Allen et al. 2018; Box et al. 2019; Meredith et al. 2019). In northern Canada, the mean annual temperature has increased by $2.3{ }^{\circ} \mathrm{C}$ since 1948 , which is $0.6^{\circ} \mathrm{C}$ above the Canada-wide average (Bush \& Lemmen 2019). In Svalbard, an archipelago in the Norwegian High Arctic, the mean annual temperature (as measured at Svalbard Airport, Longyearbyen) has risen by $3.7{ }^{\circ} \mathrm{C}$ since 1900 (Hanssen-Bauer et al. 2019). Parts of northern Norway (defined here to exclude Svalbard) have experienced an above-average increase

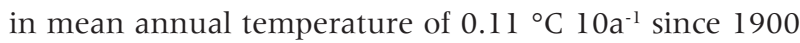
compared to the rest of mainland Norway $\left(0.09{ }^{\circ} \mathrm{C}_{\left.10 \mathrm{a}^{-1}\right)}\right.$ (Hanssen-Bauer et al. 2015). In response to this enhanced warming signal, Arctic ice masses are receding rapidly and are currently the largest contributor to global sealevel rise (Box et al. 2018).

Norwegian glaciers (defined here to include only glaciers in mainland Norway), of which roughly $40 \%$ lie within the Arctic Circle (Fig. la), exhibited a net frontal retreat over the course of the 20th century (Andreassen et al. 2005). This retreat has accelerated since the beginning of the 21 st century (Weber et al. 2019; Andreassen et al. 2020). The last major expansion of ice masses in Norway occurred during the LIA (Grove 2004), with the 


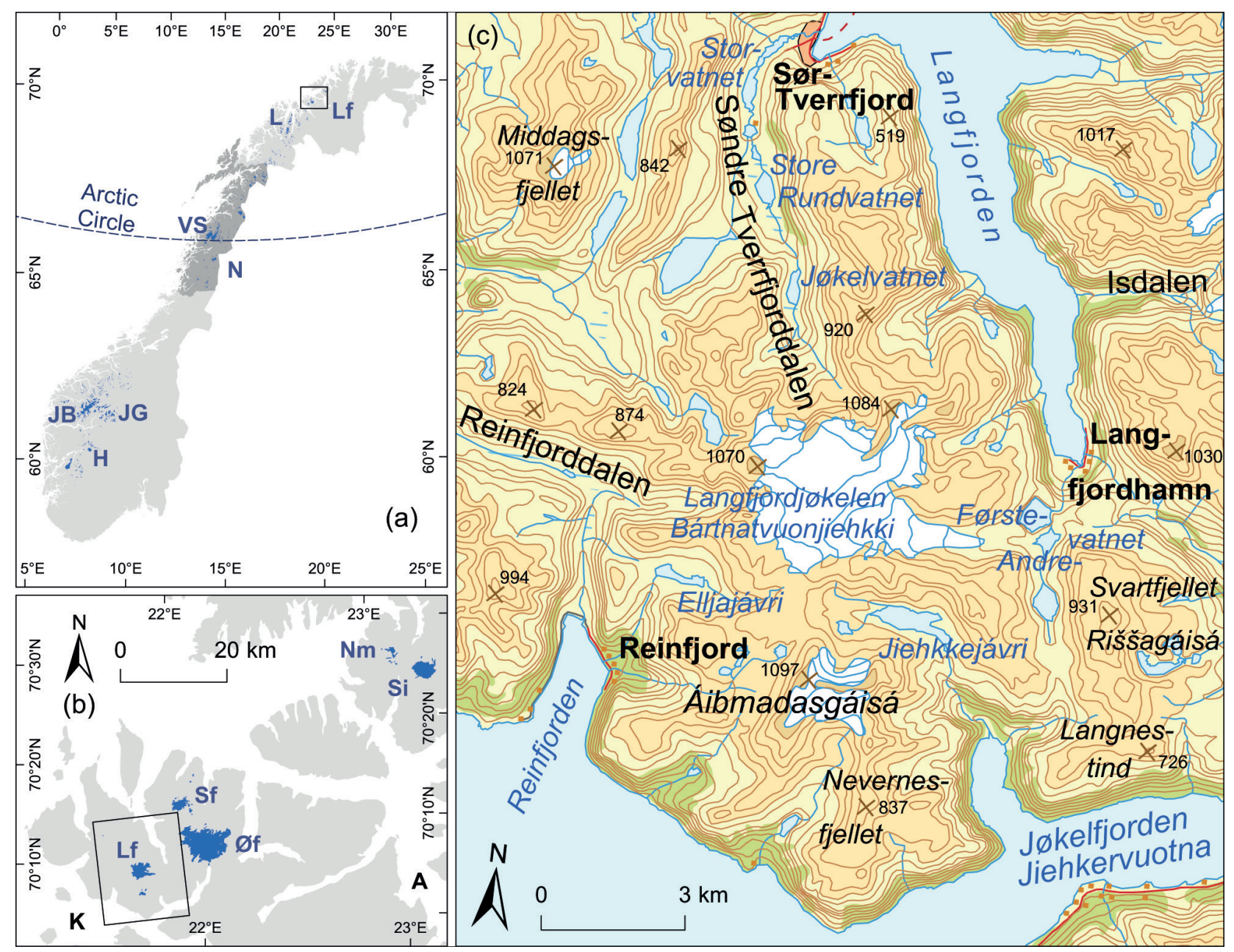

Fig. 1 (a) Latitudinal distribution of ice masses in mainland Norway. Glacier inventory data from Andreassen, Winsvold et al. (2012). H: HardangerjøkuIen; JB: Jostedalsbreen; JG: Jotunheimen glaciers; N: Nordland glaciers (Nordland county is shaded in dark grey); VS: Vestre Svartisen; L: glaciers on the Lyngen Peninsula; Lf: Langfjordjøkelen. Rectangle indicates area shown in (b). (b) Ice masses in the northernmost part of Arctic mainland Norway. Øf: Øksfjordjøkelen (Ákšovuonjiehkki); Sf: Svartfjelljøkelen; Si: Seilandsjøkelen (Nuortageašjiehkki); Nm: Nordmannsjøkelen (Dáččavuonjiehkki). A: Altafjorden; K: Kvænangen (Návuotna). Rectangle indicates area shown in (c). (c) Topographic map of Langfjordjøkelen (Bártnatvuonjiehkki) with generalized glacier extent (coordinate system: ETRS 1989 UTM Zone 33N; projection: Transverse Mercator; map data from the Norwegian Mapping Authority).

former maximum extent typically being well recorded in the form of glacial landform features such as ice-marginal moraines (e.g., Erikstad \& Sollid 1986), making the LIA limit a convenient baseline to examine long-term glacier change (Baumann et al. 2009; Stokes et al. 2018; Weber et al. 2019). Many Norwegian glaciers reached their maximum LIA positions in the 18th century (e.g., Bickerton \& Matthews 1993; Winkler 2003; Grove 2004; Matthews 2005). Amongst the notable exceptions (e.g., Tvede 1973) are the glaciers on the Lyngen Peninsula (Fig. la) and the icefields in the Kvænangen (Návuotna) fjord area (Fig. 1b) in Arctic mainland Norway, where LIA advances occurred in the early 20th century (Ballantyne 1990; Bakke et al. 2005; Wittmeier et al. 2015). In particular, the Langfjordjøkelen (Bártnatvuonjiehkki) icefield (Fig. 1c) attained its LIA maximum as late as about 1925 ( \pm 20 years) (Wittmeier et al. 2015). Its exact maximum extent, however, is largely unknown and has not been mapped systematically to date. A historical gradteigskart map shows the icefield extent in 1891/1902, presumably in a state of advance to its maximum limits. Winsvold et al. (2014) used the mapped outline to calculate glacier change to the year 2006 and found that Langfjordjøkelen had diminished in area and length by 62 and 
$43 \%$, respectively. Modelling and geodetic measurements of Langfjordjøkelen's mass balance indicate a sustained decline of the icefield since the late 1940s (Andreassen, Kjøllmoen et al. 2012; Kjøllmoen 2019; Andreassen et al. 2020). Moreover, geodetic and direct mass balance measurements at the icefield (covering the periods 1966-2008 and 1989-2008, respectively) reveal the largest mass loss of all Norwegian glaciers with available mass balance records (Andreassen, Kjøllmoen et al. 2012; Andreassen et al. 2020).

Here, we reconstruct Langfjordjøkelen's dimensions at the LIA maximum to serve as a baseline to assess icefield change over the last 100 years in greater detail. This allows the magnitude of the icefield's recent rapid decline to be placed in a centennial-scale context. It also provides an opportunity to investigate the potential occurrence of amplified glacier retreat in northern Norway. The objectives of this research are thus threefold: (1) to establish Langfjordjøkelen's maximum LIA extent from the glacial landform record preserved around the icefield, (2) to determine the accuracy of the historical mapping by comparing our reconstructed LIA outline with the map-based 1891/1902 glacier extent and (3) to quantify and discuss icefield area and length change since the LIA maximum.

\section{Study area}

Langfjordjøkelen is a maritime plateau icefield in Arctic mainland Norway at $70^{\circ} 10^{\prime} \mathrm{N}, 21^{\circ} 45^{\prime} \mathrm{E}$ (Fig. 1). It is one of Norway's northernmost ice masses and forms part of a group of five major icefields that cover the roughly 1000-m-high summit areas of the steep-sided mountain plateaux on the island of Seiland and on the peninsula between Kvænangen and Altafjorden (Fig. 1b). In 2018, the icefield was $6.4 \mathrm{~km}^{2}$ in area and spanned an elevation range from $1042 \mathrm{~m}$ a.s.l. on the icefield summit to $338 \mathrm{~m}$ a.s.l. at the front of the major eastern outlet glacier (Kjøllmoen 2019; Kjøllmoen et al. 2019). Direct mass balance measurements at the eastern outlet (informally called Langfjordjøkelen East) since 1989 have documented a cumulative mass balance of $-27.9 \mathrm{~m}$ w.e. until the end of the 2018/19 balance year (Kjøllmoen 2019; NVE 2019), which includes modelled values for the years 1994 and 1995 (Andreassen, Kjøllmoen et al. 2012). In situ length change measurements since 1998 have revealed a cumulative frontal retreat of $618 \mathrm{~m}$ to present (autumn 2019) (Kjøllmoen et al. 2019; NVE 2019). Langfjordjøkelen's LIA maximum in ca. 1925 was established by analysis and age-depth modelling of lacustrine sediments retrieved from a chain of distal glacier-fed lakes in the Søndre Tverrfjorddalen (Bártnatvuonvággi) valley to the north of the icefield (Fig. 1c) (Wittmeier et al. 2015). The study employed principal component analysis to link the characteristics of the LIA lake sediments to those of samples taken from a moraine of inferred LIA origin. Wittmeier et al. (2015) stated an uncertainty of \pm 20 years for their LIA date. There are only sparse historical records to independently verify the timing of the LIA in this region. Travellers' accounts, old photographs and drawings of the neighbouring Øksfjordjøkelen (Ákšovuonjiehkki) icefield (Fig. lb) suggest that the described and depicted outlet glaciers were at extended positions (seemingly at or close to their LIA limit) throughout the second half of the 19th century (Forbes 1853; Hardy 1862; Geikie 1892; Thoner 1906; see also summaries in Hoel \& Werenskiold 1962; Whalley \& Kjøllmoen 2000). Hardy (1862) observed in 1859 that the hanging glacier tongue (called Øverisen or Badjejiehkki) of Øksfjordjøkelen's southern plateau-based outlet Isfjordjøkelen was still connected to the fan-shaped reconstituted glacier (called Nerisen or Vuollejiehkki) at the foot of the plateau, but that this connection was beginning to disintegrate rapidly. Geikie (1892) reported that Nerisen was fully detached from the plateau ice in 1865. Between 1887 and 1902, all five icefields in the region were surveyed by the Norwegian Geographical Survey (Norges Geografiske Oppmåling; now the Norwegian Mapping Authority [Kartverket]) for the 1:100 000 scale topographic gradteigskartene maps, which depict the glaciers as expansive plateau icefields with sizeable outlet glaciers. There is no available documentary evidence of the state of the icefields in the early 20th century before the first oblique aerial photographs of the region were taken in the late 1930s. All five icefields receded throughout the 20th century (Whalley \& Kjøllmoen 2000; Winsvold et al. 2014).

\section{Methods and data}

\section{Geomorphological mapping and LIA reconstruction}

Reconstructing the LIA extent of Norwegian glaciers and icefields is done by mapping the clear glacial geomorphological evidence at the margins of the modern ice masses, and in particular the stark boundaries between fresh, glacially eroded terrain and weathered, vegetated areas (e.g., Ballantyne 1990; Stokes et al. 2018; Weber et al. 2019; Weber et al. 2020). Following a standard approach outlined by Chandler et al. (2018), we mapped glacial landforms and terrain boundaries remotely in ArcGIS from high-resolution $(0.25 \mathrm{~m})$ digital colour vertical aerial photographs captured on 20-21 August 2015 (acquired from http://norgeibilder.no/; Table 1). The remote mapping was subsequently ground-truthed during a three-week field campaign in July/August 2017. The landform and terrain features identified at Langfjordjøkelen (Fig. 2) 
Table 1 Overview of remotely sensed icefield outlines of Langfjordjøkelen.

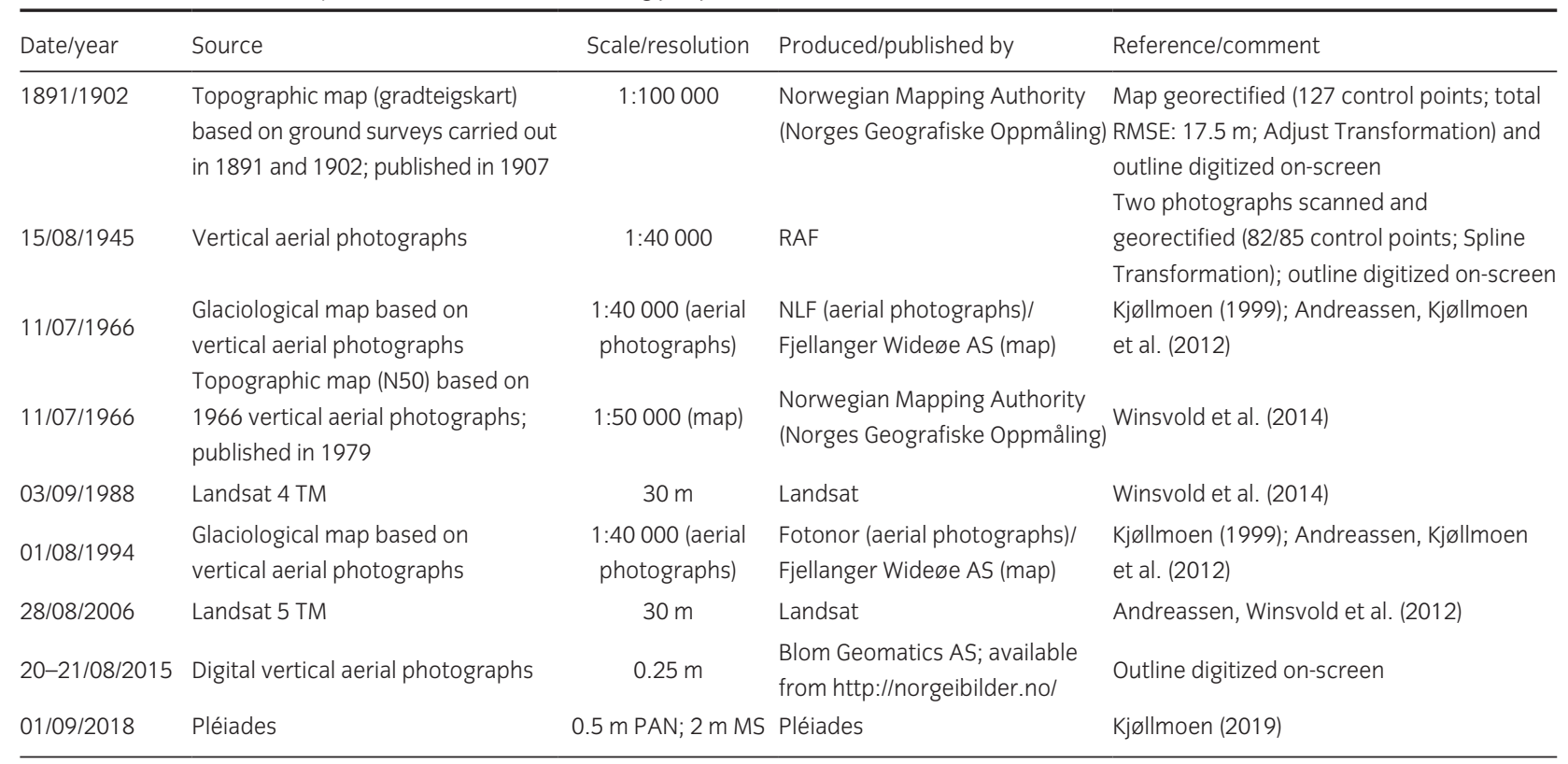

include ice-marginal moraines, glacial trimlines, glacial drift limits (boundary between a surface composed of fresh and sparsely vegetated glacially derived material [presumed LIA] and drift-free [presumed older] terrain beyond) and erosional/weathering boundaries (boundary between freshly ice-moulded [presumed LIA] and more weathered [presumed older] bedrock) (see Fig. 3d). Field mapping took place around the entire icefield except for the relatively inaccessible north-eastern sector (Nordmanndalen and Trolldalen [Skuonasvággi] valleys). Moraine positions were recorded using a handheld GPS unit that provided maximum accuracy of $4 \mathrm{~m}$. In the final step, we used the outermost LIA glacial landforms and terrain boundaries as a framework to reconstruct Langfjordjøkelen's outline at the LIA maximum. The gaps between the landform-based sections of the outline were then interpolated and classified as either fairly or less certain (Weber et al. 2019). Outline segments were less certain when the interpolated line could have also been drawn either closer to the present-day glacier margin (resulting in a smaller outline) or extending further away (indicating an even larger outline).

\section{Historical map processing}

The historical gradteigskartet map of Langfjordjøkelen shows evidence of incorrectly mapped topographic features in both their shape and geographical location (described in more detail later in this article). In an attempt to rectify as many of these inaccuracies as possible, we georeferenced the map sheet again (which had been done before by Winsvold et al. 2014) by creating a total number of 127 control points in the immediate surroundings of the icefield. Many of the control points were placed in a way that landscape features such as lake shorelines and mountaintops could be dragged to their correct geographical location. We then georectified the map using an Adjust Transformation and manually digitized the icefield outline.

\section{Icefield outlines and glacier change assessment}

The reconstructed LIA outline together with other available outlines of Langfjordjøkelen since 1945 (Table 1) was used to examine rates of glacier area and length change in the period ca. 1925-2018, the most recent icefield outline being based on a Pléiades satellite scene from 1 September 2018. The 1945 outline of Langfjordjøkelen was produced for the purpose of this study by georectifying scanned aerial photographs taken by the British RAF (>80 control points; Spline Transformation) and by manually digitizing the icefield extent (Table 1). All icefield outlines were subdivided into glacier units along the drainage divides established by Andreassen, Winsvold et al. (2012), which had to be extended and adjusted to fit the LIA icefield dimensions. Glacier area change per glacier unit and for the icefield as a whole was calculated for each time interval and for the overall measurement period. We used compound interest 


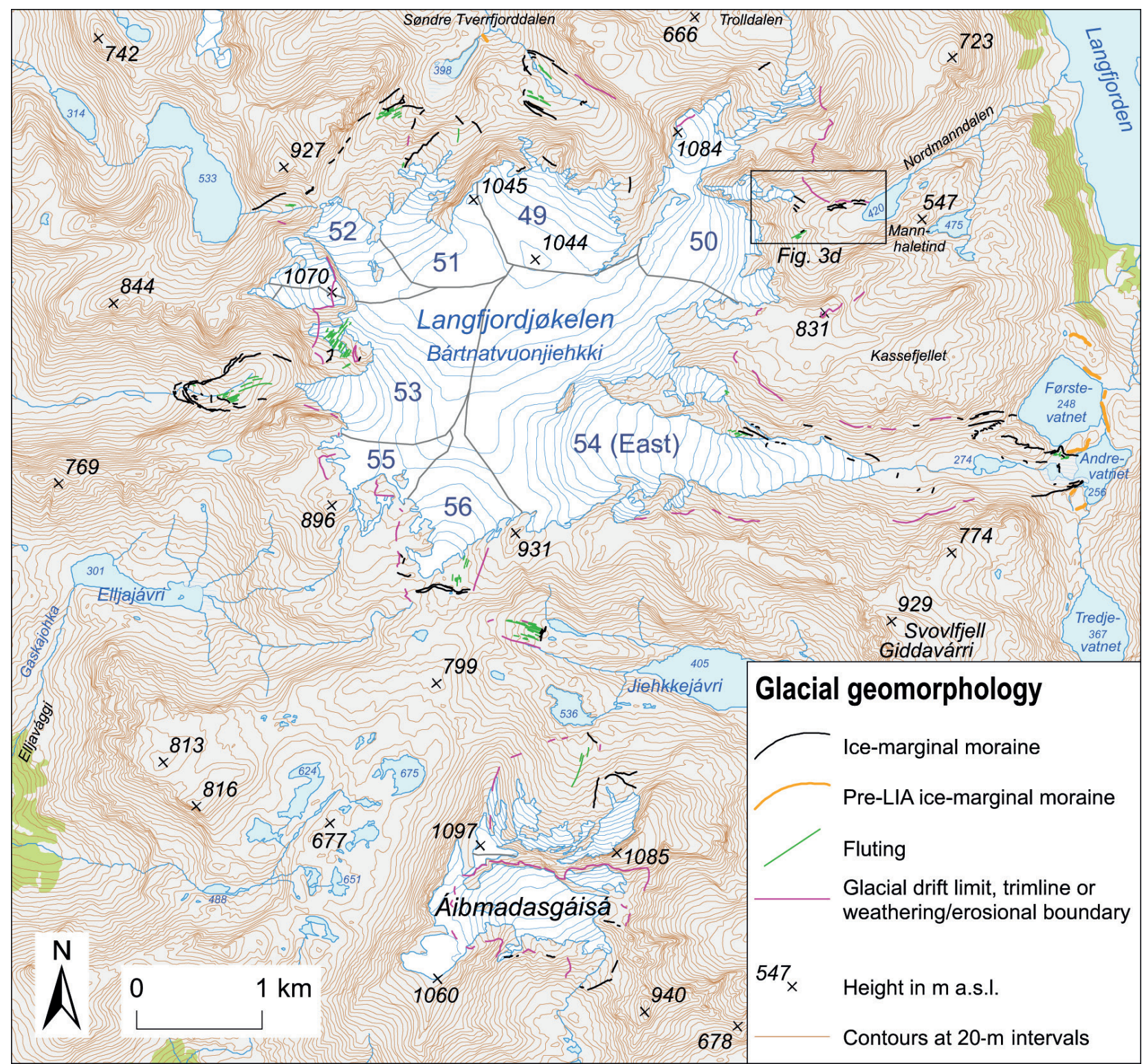

Fig. 2 Glacial geomorphological landforms at the margins of Langfjordjøkelen, as mapped from 2015 digital vertical aerial photographs (see Table 1) and field-checked in July/August 2017. The topographic base map (Norwegian Mapping Authority) shows the icefield extent in September 2008 and includes ice-marginal snow, which is why some of the landform features formed after this time appear to lie within the 2008 glacier limits. Glacier ID numbers 49-56 denote individual icefield drainage basins (established by Andreassen, Winsvold et al. 2012). Rectangle indicates area shown in Fig. 3d.

calculation (Andreassen et al. 2008; Zemp et al. 2014) to compute decadal rates of area change. Cumulative length change and rates of length change were measured along glacier centrelines. Guided by the 1966, 1988 and 2006 centrelines previously created for Langfjordjøkelen by Winsvold et al. (2014), we digitized one principal centreline per icefield unit by connecting the glacier head with the furthest downvalley point (terminus) of each glacier outline. Ice-marginal snow included in remotely sensed glacier outlines (see Table 1) can introduce glacier area uncertainties of $5-10 \%$ for larger $\left(>5 \mathrm{~km}^{2}\right)$ ice masses and up to $25 \%$ for smaller $\left(<1 \mathrm{~km}^{2}\right.$ ) glaciers (Paul \& Andreassen 2009). Although not quantified here, these values are a realistic error estimate for our change assessment. 

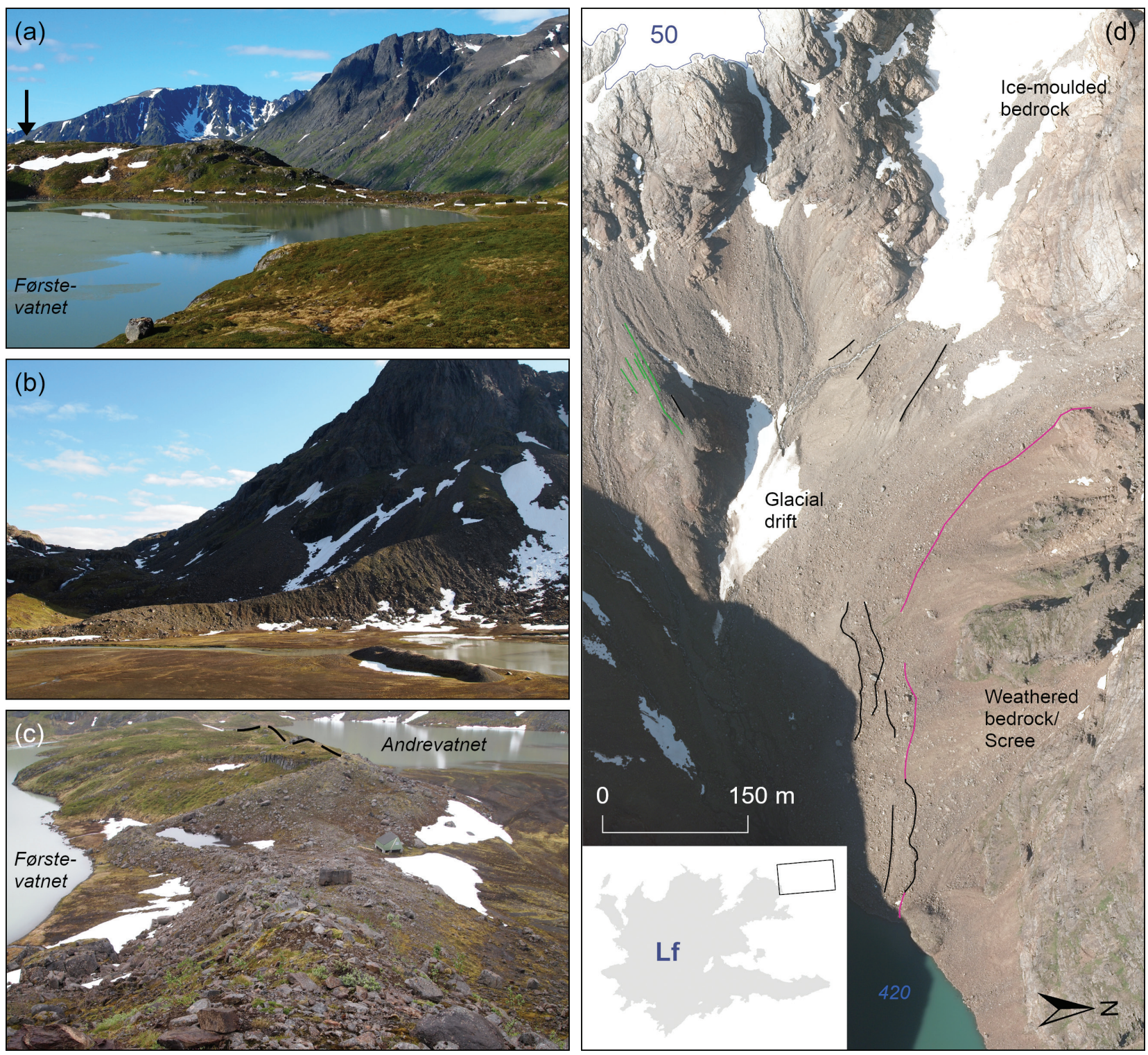

Fig. 3 (a) Well-vegetated pre-LIA moraines are preserved around Førstevatnet (crestline of the moraines indicated by white dashed lines and a black arrow), delimiting the extent of a cirque glacier of presumed Younger Dryas age (Evans et al. 2002). View towards the north-east. (b) LIA lateral moraine ridge deposited by Langfjordjøkelen East at the southern valley mouth. A frontal recessional moraine lies in the middle of the valley floor, surrounded by glacial outwash deposits. View towards the south. (c) LIA lateral moraine complex deposited by Langfjordjøkelen East at the northern valley mouth. The ridge system forms a small lobe on the south bank of Førstevatnet. The green hut inside the LIA moraine limit is owned by NVE. Note the well-vegetated, subdued pre-LIA cirque moraine on top of the bedrock ridge between Første- and Andrevatnet (moraine crestline indicated by black dashed line). View towards the east. (d) Glacial landform record associated with the maximum LIA extent in the Nordmanndalen valley. See Fig. 2 for legend. Ice-marginal moraines and a sheet of fresh-looking, unvegetated glacial drift indicate that an LIA outlet glacier extended from drainage basin 50 down to the unnamed lake at $420 \mathrm{~m}$ a.s.I. The slope below the plateau is occupied by an elongated, streamlined bedrock hummock. Its stoss side is draped with fluted drift and topped by a medial moraine. Note the scree deposits and the weathered bedrock beyond the LIA glacial drift limit. The inset shows the location of the photographed area in the north-east of the present-day icefield (August 2015 vertical aerial photographs acquired from http://norgeibilder.no/; see Table 1). 


\section{Results}

\section{Identifying the LIA extent from geomorphological evidence}

Langfjordjøkelen's maximum LIA extent is typically delineated by major, well-defined, sparsely vegetated and often bouldery moraine ridges in the valleys radiating from the glacier-covered plateau. These valleys are narrow, steepsided and dominated by mass movement processes on the slopes. Active talus and debris flow deposits cover the sides and base of the valleys so that there is little glacial landform evidence between the outer LIA moraines and the present-day ice margin. The talus outside the LIA limit often appears more stable and vegetated, providing an indication of the maximum LIA extent. Also occurring outside the LIA limit in many of the valleys are suites of mature, round-crested and well-vegetated moraines (Fig. $3 a, c)$, which we presume define the maximum Younger Dryas extent and subsequent recession of the icefield and neighbouring glaciers (Evans et al. 2002). The results of the geomorphological mapping are presented in Fig. 2.

At Langfjordjøkelen East, the lateral margins of the glacier tongue are mantled in debris, and ice-cored morainic mounds are present along the northern part of the terminus. Glaciofluvial outwash deposits occupy large parts of the valley floor down to the Andrevatnet lake. Here, prominent, sharp-crested and sparsely to moderately vegetated lateral moraine ridges mark the outlet's maximum LIA position (Fig. 3b, c). A large (>20 $\mathrm{m}$ high) lateral moraine was deposited on the southern side of the valley mouth (Fig. 3b). The height of its crest gradually reduces towards the lake where the ridge terminates in a small cluster of lateral moraines. The LIA lateral moraine on the northern side of the valley mouth attains heights of up to $10 \mathrm{~m}$ and forms a small lobe in front of the Førstevatnet lake (Fig. 3c). A handful of discontinuous moraines occur immediately inside the ridge on a narrow patch of distinctly fluted drift. On the sandur fan in the middle of the LIA foreland, approximately $150 \mathrm{~m}$ from the lakeshore, lies a round-topped, slightly winding recessional end moraine composed of sands with gravel and pebble clasts and a few boulders incorporated in its flanks (Fig. 3b). This moraine is likely to reflect an episode of post-LIA ice front stability or minor glacier advance. The northern LIA-age lateral moraine meanders up the crest of a prominent foothill that projects from the northern base of the plateau and extends halfway across the valley. In the narrow, debris-choked gorge between this foothill and the plateau flank that rises towards the Kassefjellet peak, a series of latero-frontal recessional moraines demonstrates that the LIA glacier tongue split around this semi-detached peak, and a small side tongue extended down the gorge towards Førstevatnet. On the plateau flank above the gorge, a distinct trimline, interspersed by lateral moraines, runs along the entire length of the valley side onto the plateau summit, rising from about $357 \mathrm{~m}$ a.s.l. at the valley mouth to about $722 \mathrm{~m}$ a.s.l. on the plateau.

In the valleys along the north-eastern icefield sector, sparse glacial landform evidence in the form of drift limits, erosional boundaries and ice-marginal moraines (identified remotely from aerial photograph interpretation) tentatively indicates the maximum LIA extent. This evidence is strongest in the Nordmanndalen valley, where lateral moraines and a relatively continuous drift limit along the northern valley side suggest that the LIA ice front advanced to the unnamed lake (420 m a.s.l.) currently occupying the valley floor (Fig. 3d).

The northern icefield sector overlooks the head of the presently ice-free Søndre Tverrfjorddalen valley system. Here, geomorphological evidence indicates that three outlet glaciers extended from the plateau during the LIA maximum. These can also still be seen on historical aerial photographs from 1936-39 and 1952 (Fig. 4a, d). The easternmost LIA outlet (originating from drainage basin 49) flowed down a U-shaped trough to ca. $485 \mathrm{~m}$ a.s.l., as evidenced by predominantly openwork, clast-supported, bouldery outer latero-frontal moraines comprising up to two sets of inset moraine ridges. Exposed bedrock on the valley floor is ice-moulded, contrasting with the weathered bedrock outside the LIA limit. The LIA lateral moraine on the north-eastern valley side links up with a sharp glacial trimline that leads onto the plateau. A former LIA outlet issuing from drainage basin 51 deposited sharp-crested to round-topped outer moraine ridges down to an elevation of about $513 \mathrm{~m}$ a.s.l. (Fig. 4b). Heavily ice-moulded bedrock occurs inside this limit. Wittmeier et al. (2015) collected sediment samples from the continuous, winding lateral moraine ridge along the north-western side of the foreland (their moraine M13) for principal component analysis and comparison with the lacustrine LIA sediment record. A third LIA outlet glacier was fed by ice from drainage basin 52 in the north-west of Langfjordjøkelen (confluent with outlet 51 in the upper part of the glacier trunk). Ice from this basin flowed in a north-westerly direction through a low saddle into a north-east-oriented, chute-like stretch of the valley. Today, only the saddle is still filled by ice, which the 2018 Pléiades imagery shows has become detached from the icefield. Down in the valley, the former outlet split into two branches, producing a double moraine ridge on the north-western valley side. A short, west-flowing branch extended down to, but did not quite reach, the unnamed lake (533 $\mathrm{m}$ a.s.l.) to the north-west of Langfjordjøkelen, as indicated by a well-defined lateral 

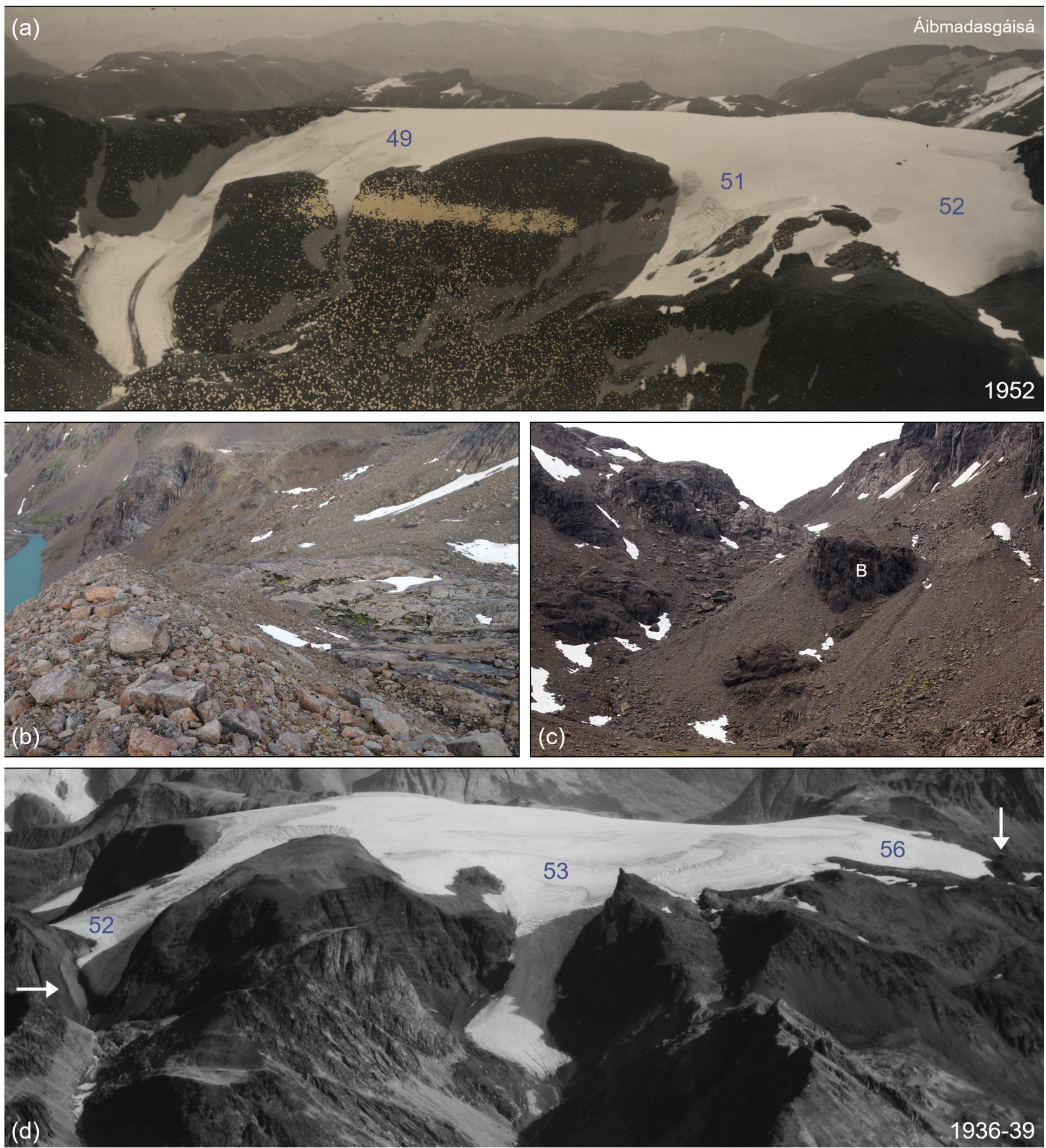

Fig. 4 (a) Oblique aerial photograph of Langfjordjøkelen's northern flank from 31 July 1952. Numbers indicate icefield unit IDs. The view is towards the south and the Áibmadasgáisá massif with its northern cirque glacier is seen in the distance to the right (Photo: V. Skappel, Widerøes Flyveselskap AS; owner: National Library of Norway). (b) LIA lateral moraine ridge and ice-moulded foreland of the former outlet glacier extending from drainage basin 51. This is moraine M13 of Wittmeier et al. (2015). The view is towards the north-east and the lake in the distance to the left is the unnamed lake at $398 \mathrm{~m}$ a.s.l. (c) Landform assemblage at the former terminus of the LIA outlet glacier extending from drainage basin 52. The glacier front split around the bedrock protrusion (B) on top of the debris-covered slope. Moraine ridges indicate that the glacier tongue to the right (north) of the bedrock protrusion terminated on top of the slope, whilst the glacier tongue to the left (south) of the protrusion descended halfway down the slope. (d) Langfjordjøkelen's western flank photographed between 1936 and 1939 (Photo: Widerøes Flyveselskap AS; owner: National Library of Norway). Numbers indicate icefield unit IDs. White arrows indicate major moraine ridges described in the main text. 
moraine ridge on the northern valley side above the lake (Fig. 4d). The main branch of the outlet trended in a north-easterly direction to the edge of a steep, debris-covered slope, forming bench-like lateral moraine segments along the north-western valley side during outlet recession. At the edge of the slope, the outlet terminus split further into two tongues around an intervening bedrock protrusion (Fig. 4c). This created a sharp-crested bifurcating moraine complex in the middle of the debris-choked, fluted valley floor. The north-western tongue ended at the upper slope edge at about $520 \mathrm{~m}$ a.s.l., which is documented by a major lateral moraine paralleling the bifurcating ridge complex along the north-western valley side. By contrast, the south-eastern tongue descended halfway down the slope to about $460 \mathrm{~m}$ a.s.l., depositing sharp- to round-crested lateral moraines. Both tongues appear to have sent large quantities of debris down the slope. Our mapping in this sector contrasts with that of Wittmeier et al. (2015), who placed the LIA limit on the far (northern) side of the unnamed lake situated below the slope at $398 \mathrm{~m}$ a.s.l. Their reconstruction is based on a reportedly unvegetated moraine ridge on the northern lake shore (their moraine M12), which we were unable to identify and verify. However, we found evidence of a mature-looking, well-vegetated moraine fragment of presumed pre-LIA age in a nearby position.

The LIA icefield limit along the western edge of the plateau summit is often clearly delineated by glacial drift limits. Flutings and moraine fragments on the plateau edge show that ice flow out of drainage basin 53 was funnelled entirely into the U-shaped valley stretching to the west, which hosted a sizeable LIA outlet glacier. The maximum extent and subsequent ice front fluctuations of this LIA outlet are marked by a system of nested bouldery latero-frontal moraines that can be traced almost continuously around the inner valley (Fig. 4d). Today, only a minor ice tongue is occupying the upper valley headwall below the plateau edge.

In the south of the icefield (drainage basin 56), a multicrested end moraine complex, single moraine ridges, discontinuous drift limits and flutings define the maximum LIA extent of a sheet-like glacier lobe that spread across, but did not descend from, the southern plateau summit area. The oblique aerial photograph in Fig. $4 d$ shows that the outlet lobe still stood at the moraine complex in 193639. Just to the south-east of this lobe, a small, independent ice patch of presumed LIA age existed on the plateau flank above the Jiehkkejávri lake, as indicated by a well-delimited sheet of fluted drift with a sequence of frontal moraine ridges at its downvalley end. The LIA extent of the two cirque glaciers of the Áibmadasgáisá massif is demarcated by ice-marginal moraines and erosional boundaries.

Our reconstructed LIA outline has a total perimeter length of $33.4 \mathrm{~km}$ (Fig. 5). Just over one-third (36.5\%; $12.2 \mathrm{~km}$ ) of this length is based on unambiguous landform evidence and can therefore be classified as certain.

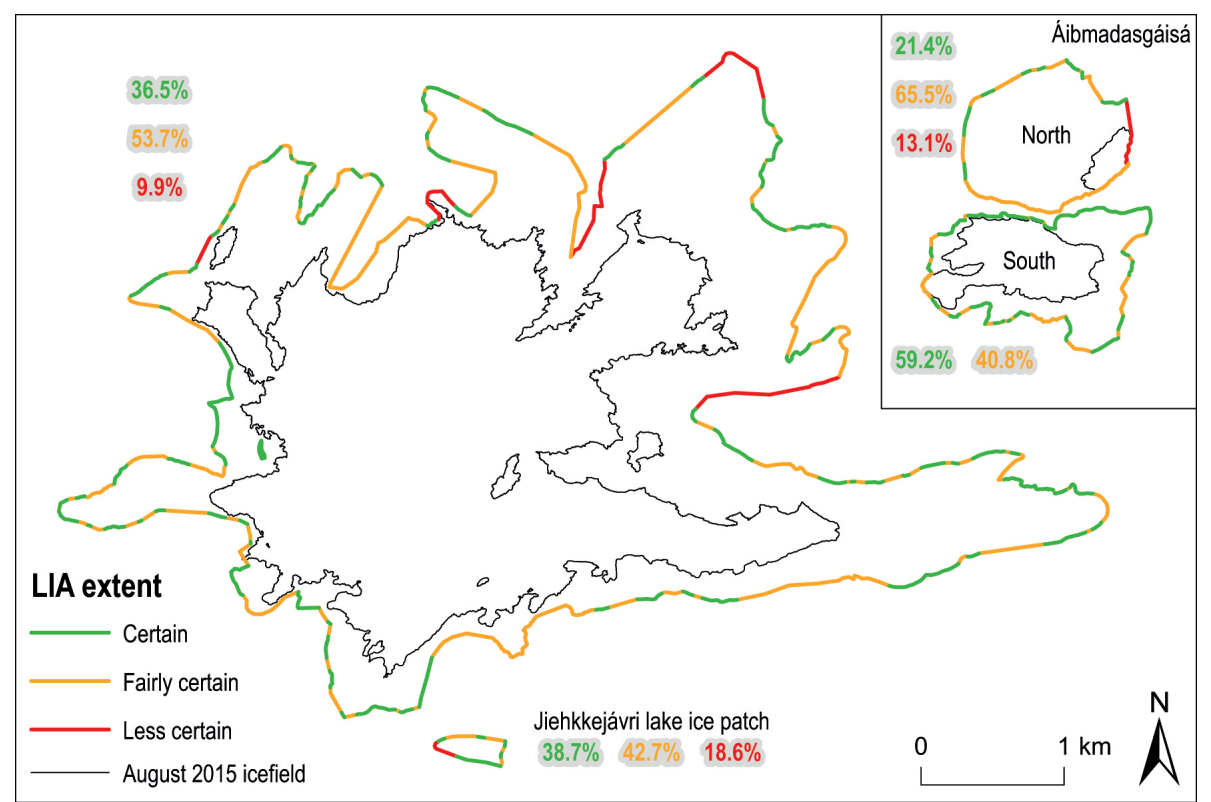

Fig. 5 Reconstructed maximum LIA extent of Langfjordjøkelen and the Áibmadasgáisá cirque glaciers, classified into different levels of confidence. The green sections of the outline (certain) represent mapped glacial landform features. The 2015 glacier extent (see Table 1) is shown for comparison, which is the most recent outline available for the cirque glaciers. 
Guided by the topography of the terrain and historical aerial photographs, approximately half of the length $(53.7 \% ; 17.9 \mathrm{~km})$ was reliably interpolated between the evidence-based sections of the outline and can be classified as fairly certain. Most of the icefield's outlet glaciers fall into these two categories as ice-marginal landforms preferentially form at the glacier snout, where they are often abundant and closely spaced. An exception is the southern LIA margin of Langfjordjøkelen East, which was established by mirroring the reconstructed LIA margin along the northern valley side, due to a paucity of glacial landforms or evidence. Only one-tenth of Langfjordjøkelen's LIA outline $(9.9 \% ; 3.3 \mathrm{~km})$ is assessed to be less certain and had to be inferred from the topography alone, representing a best-guess interpolation. This is particularly the case for the LIA extent in drainage basin 50, where landform evidence on the plateau summit is sparse, leaving the possibility that the LIA ice in the Trolldalen valley was not connected to the main icefield (however, this would have only a minor effect on the area of the reconstructed LIA outline because the icefield and Trolldalen are only separated by a narrow ridge). The three separate LIA ice masses to the south of Langfjordjøkelen, informally named Jiehkkejávri ice patch, Áibmadasgáisá North and Áibmadasgáisá South, have a perimeter length of 1.2, 3.8 and $5.2 \mathrm{~km}$, respectively (Fig. 5).

\section{Comparison with map-based 1891/1902 icefield extent}

Langfjordjøkelen's reconstructed LIA extent has a total area of $14.9 \mathrm{~km}^{2}$. This compares to an area of $20.6 \mathrm{~km}^{2}$ calculated for the 1891/1902 icefield extent, suggesting that the icefield was substantially larger in 1891/1902 than at its LIA maximum (dated to ca. $1925 \pm 20$ years; Wittmeier et al. 2015). In particular, the southern icefield sector is more extensive than the maximum LIA extent indicated by our reconstruction, including an additional outlet glacier in the east of the icefield (Fig. 6). On closer inspection, however, several map inaccuracies become apparent. The topography shown on the map appears smoothed, and a number of topographic features (or their geographical location) were mapped incorrectly, resulting in the georeferencing problems described earlier in this article. A good example of this is the northern Áibmadasgáisá cirque, which was mapped as a convex mountain flank. Entirely missing from the map are the two prominent lakes Elljajávri and Jiehkkejávri to the south-west and south-east of Langfjordjøkelen, respectively (Fig. 6). The Jiehkkejávri lake basin is instead occupied by the additional eastern outlet glacier (for which there is no geomorphological evidence). These lakes are situated in high mountain valleys and are difficult to see unless one is in close proximity to them or at a higher elevation. Their absence from the map, therefore, implies that the field surveyors did not visit the area around the southern sector of Langfjordjøkelen directly but carried out the mapping from a distance. As a result, seasonal or perennial snow present on the plateau summit at the time of the surveys may have been mistaken for glacier ice and included in the icefield outline. (An assessment of historical map accuracy in Nordland [Fig. la] by Weber et al. [2020] generally showed a higher quality of the glacier mapping than here at Langfjordjøkelen; in Nordland, mapping errors and the inclusion of ice-marginal snow seemed to be more of a problem at smaller glaciers.) An additional possibility is that prolonged lake ice at Jiehkkejávri after a severe winter and a cool spring may have been misinterpreted as an outlet glacier by the surveyors. Based on these inconsistencies and inaccuracies, we judged the 1891/1902 icefield extent to be overestimated (by 38\% compared to our reconstructed LIA extent) and, therefore, excluded it from the following glacier change assessment.

\section{Icefield change LIA (1925)-2018}

The reconstructed maximum LIA extent of Langfjordjøkelen (using 1925 as the basis of our calculations) can be compared with more recent as well as the present-day (2018) icefield extent (Table 1) in order to quantify almost a century of glacier areal and length change (Fig. 7; Tables 2-4). All percentage values stated in this section have been rounded to the nearest integer. In the 20 years between the estimated timing of the LIA maximum (1925) and 1945, Langfjordjøkelen's area reduced by a quarter $\left(3.7 \mathrm{~km}^{2} ; 25 \%\right)$ at a rate of $14 \% 10 \mathrm{a}^{-1}$, whilst length changes averaged $-12.1 \mathrm{~m} \mathrm{a}^{-1}$. Over the next 40 years or so, the total area loss and the rate of loss decreased, with an areal reduction of $1.3 \mathrm{~km}^{2}(12 \%)$ in the period $1945-1966\left(6 \% 10 a^{-1}\right)$ and a further reduction of $0.5 \mathrm{~km}^{2}(5 \%)$ in the period 1966-1988 (2\% $\left.10 \mathrm{a}^{-1}\right)$. By contrast, the rate of frontal retreat increased by almost $6 \mathrm{~m}$ /year to $17.6 \mathrm{~m}$ /year after 1945, before falling to $9.8 \mathrm{~m} \mathrm{a}^{-1}$ from 1966 to 1988 . The accelerated frontal retreat in the period 1945-1966 is likely a result of the disintegration of the valley-based outlet tongues of drainage basins 49-53, which had narrowed in the previous interval (LIA/1925-1945). We hypothesize that strong icefield recession in the period LIA/1925-1945 (and continued strong frontal retreat between 1945 and 1966) can be attributed to the distinct global ETCW episode, which was particularly pronounced in the Arctic, and specifically in the European Arctic (Hegerl et al. 2018). In the coastal areas of Arctic mainland Norway, including the Langfjordjøkelen region, the ETCW 

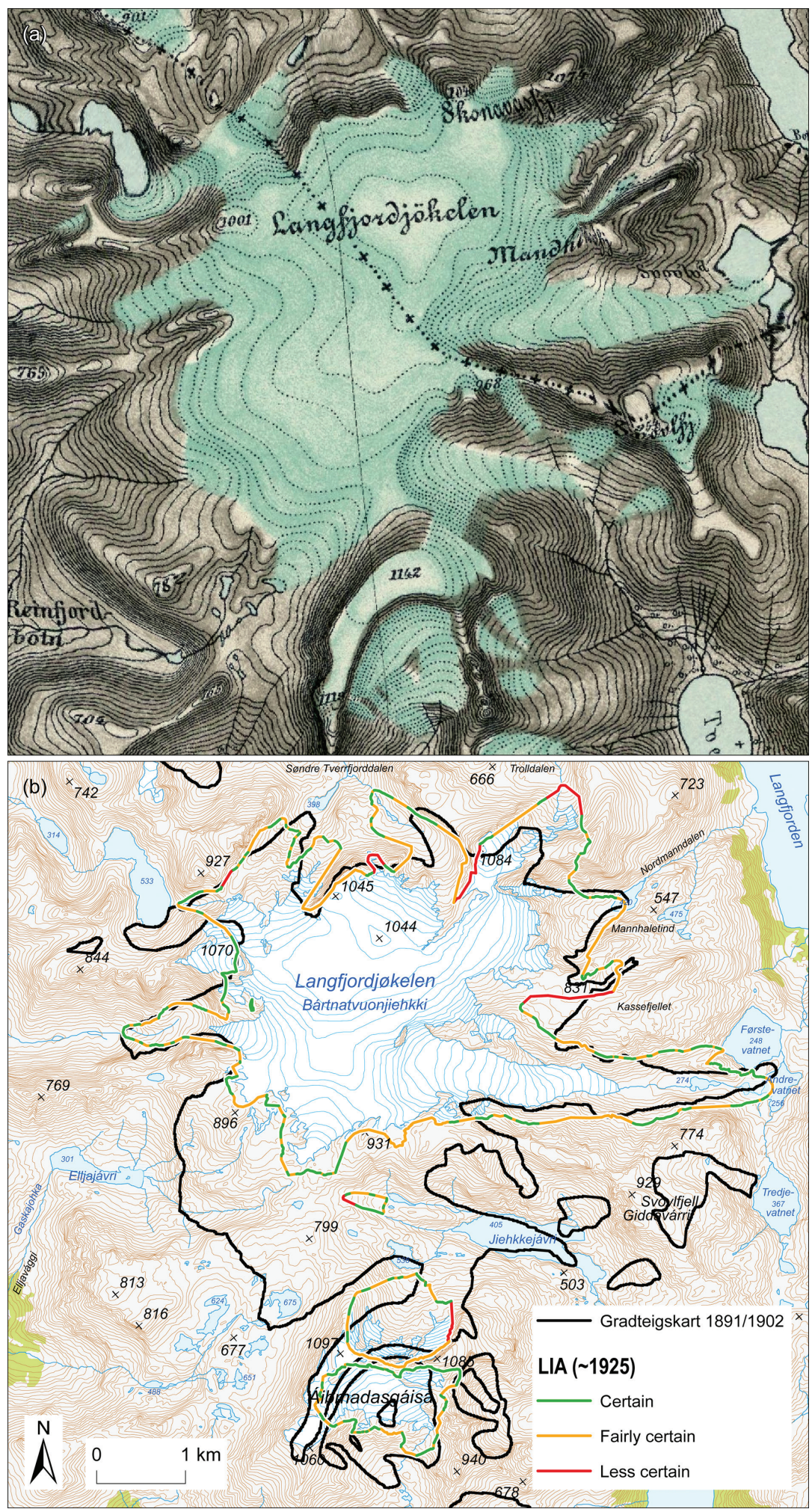

Fig. 6 (a) Georectified section of gradteigskartet map sheet S4 Bergsfjorden (1:100 000; produced by T. Lundtvedt and C. C. Olberg; published in 1907; Norwegian Geographical Survey; available from the Norwegian Mapping Authority) showing Langfjordjøkelen as surveyed in 1891/1902. (b) Comparison of icefield extent as mapped in 1891/1902 (in black) with the LIA reconstruction of this study (outline colours indicate confidence levels of margin position; see Fig. 5). Same extent and scale in both panels. 


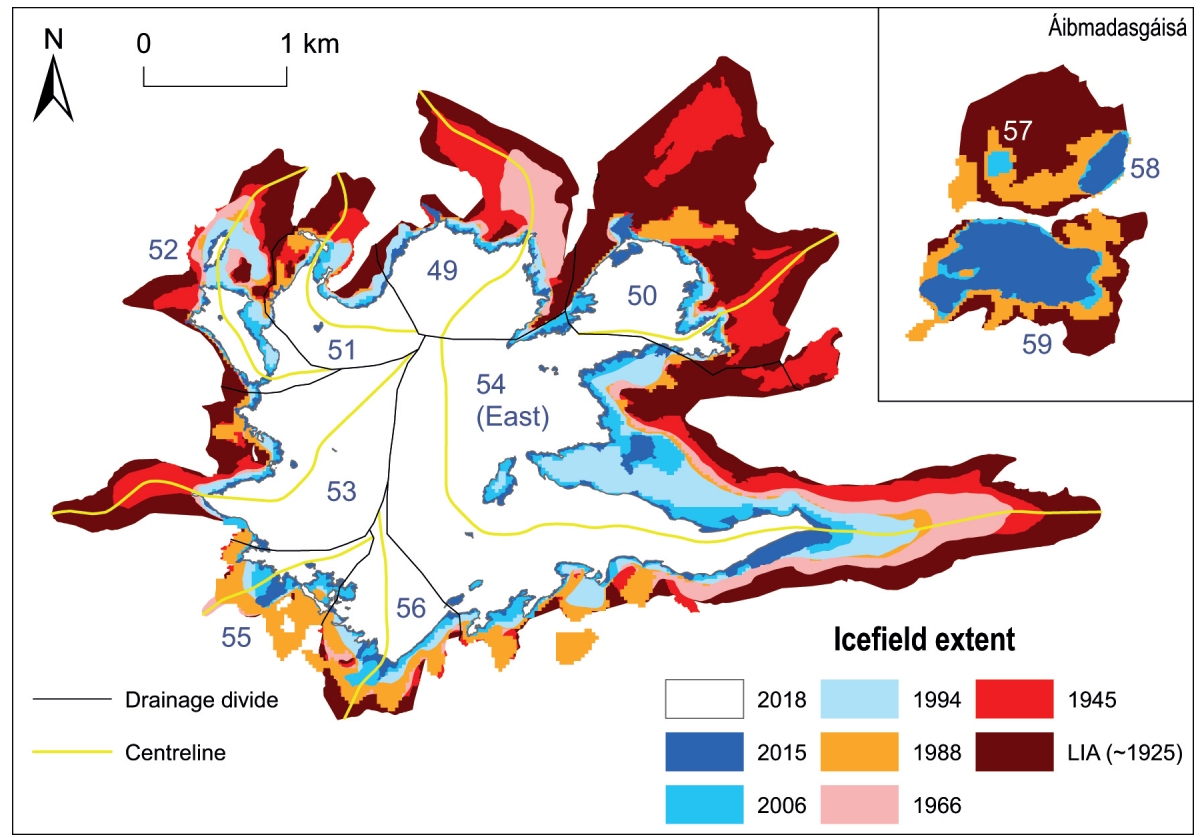

Fig. 7 Icefield recession from the LIA maximum to present using glacier outlines from successive time points. Glacier centrelines used for assessing glacier length change are shown for all icefield units. The map-based 1891/1902 icefield extent was excluded due to inaccuracies in the mapping. Inset shows the Áibmadasgáisá cirque glaciers located to the south of the main icefield (see Fig. 1c).

Table 2 Glacier area and percentage change of Langfjordjøkelen and its glacier units since the LIA (1925). Aspect data from Andreassen, Winsvold et al. (2012).

\begin{tabular}{|c|c|c|c|c|c|c|c|c|c|c|c|c|}
\hline \multirow{2}{*}{$\begin{array}{l}\text { Glacier } \\
\text { unit ID }\end{array}$} & \multirow[t]{2}{*}{ Informal glacier unit name } & \multirow[t]{2}{*}{ Aspect } & \multicolumn{9}{|c|}{ Area $\left(\mathrm{km}^{2}\right)$} & \multirow{2}{*}{$\begin{array}{l}\text { Change }(\%) \\
\text { LIA-2018 }\end{array}$} \\
\hline & & & LIA & 1945 & $1966 a$ & $1966 b$ & 1988 & 1994 & 2006 & 2015 & 2018 & \\
\hline 49 & LAJ NE & NE & 1.5 & 1.2 & 1.3 & 1.0 & 0.8 & 0.8 & 0.7 & 0.7 & 0.6 & -59.5 \\
\hline 50 & & $\mathrm{E}$ & 2.5 & 1.2 & 2.2 & 0.6 & 0.7 & 0.6 & 0.6 & 0.5 & 0.5 & -81.8 \\
\hline 51 & & NW & 0.8 & 0.7 & 0.8 & 0.6 & 0.6 & 0.6 & 0.5 & 0.5 & 0.5 & -44.8 \\
\hline 52 & LAJ NW & NW & 1.0 & 0.7 & 0.9 & 0.6 & 0.5 & 0.5 & 0.3 & 0.3 & 0.3 & -70.7 \\
\hline 53 & LAJ West & SW & 1.7 & 1.4 & 1.4 & 1.2 & 1.3 & 1.2 & 1.2 & 1.2 & 1.1 & -34.8 \\
\hline 54 & LAJ East & SE & 6.1 & 4.9 & 5.6 & 4.7 & 4.3 & 4.1 & 3.5 & 3.1 & 2.8 & -53.1 \\
\hline 55 & & W & 0.4 & 0.4 & 0.6 & 0.4 & 0.5 & 0.3 & 0.3 & 0.2 & 0.2 & -54.8 \\
\hline 56 & & s & 0.8 & 0.7 & 0.9 & 0.7 & 0.7 & 0.6 & 0.5 & 0.5 & 0.4 & -48.9 \\
\hline LAJ & Langfjordjøkelen & & 14.9 & 11.2 & 13.5 & 9.8 & 9.4 & 8.6 & 7.5 & 7.0 & 6.4 & \\
\hline 57 & Áibmadasgáisá North (ID 57) & NE & & & & & 0.1 & & 0.02 & 0 & & \\
\hline 58 & Áibmadasgáisá North (ID 58) & N & 0.9 & & 0.6 & & 0.3 & & 0.1 & 0.1 & & \\
\hline \multirow[t]{2}{*}{59} & Áibmadasgáisá South & SE & 1.0 & & 1.1 & & 0.8 & & 0.5 & 0.5 & & \\
\hline & Jiehkkejávri lake ice patch & & 0.1 & & & & & & & & & \\
\hline
\end{tabular}

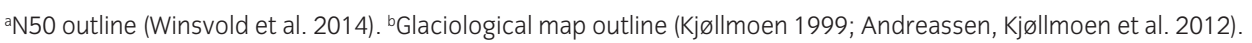

culminated in the mid-1930s, with an annual mean temperature of up to ca. $0.6{ }^{\circ} \mathrm{C}$ above the 1961-1990 average (Hanssen-Bauer 2005). Andreassen, Kjøllmoen et al. (2012) modelled Langfjordjøkelen's mass balance between 1948/49 and 1988/89, before the start of direct mass balance measurements at the icefield, and found that only six years had a positive annual balance $(>0 \mathrm{~m}$ w.e.) over this 40 -year period, with a cumulative balance of $-24.4 \mathrm{~m}$ w.e. or $-0.6 \mathrm{~m}$ w.e. $\mathrm{a}^{-1}$.

After 1988, rates of icefield shrinkage increased to $15 \%$ $10 \mathrm{a}^{-1}$ between 1988 and 1994 (exceeding the percentage value reached during the ETCW episode) and $11 \% 10 \mathrm{a}^{-1}$ 
between 1994 and 2006. Over the two measurement periods, the icefield lost a total area of approximately $2 \mathrm{~km}^{2}$. Rates of frontal retreat accelerated to $13.4 \mathrm{~m} \mathrm{a}^{-1}$ after 1988 and remained high between 1994 and 2006 $\left(12.8 \mathrm{~m} \mathrm{a}^{-1}\right)$. Icefield recession in the 1988-1994 interval is in sharp contrast to the pronounced 1990s readvance

Table 3 Comparison of rates of glacier area change at Langfjordjøkelen for each measurement period.

\begin{tabular}{|c|c|c|c|c|}
\hline \multirow[t]{2}{*}{ Period } & \multicolumn{2}{|c|}{ Total area change } & \multicolumn{2}{|c|}{ Rate of change } \\
\hline & $\mathrm{km}^{2}$ & $\%$ & $\mathrm{~km} 210 \mathrm{a}^{-1}$ & $\% 10 a^{-1}$ \\
\hline LIA ${ }^{a}-1945$ & -3.7 & -24.9 & -1.9 & -14.2 \\
\hline $1945-1966^{b}$ & -1.3 & -11.9 & -0.6 & -6.0 \\
\hline $1966-1988^{b}$ & -0.5 & -4.8 & -0.2 & -2.3 \\
\hline 1988-1994 & -0.8 & -8.5 & -1.3 & -14.6 \\
\hline 1994-2006 & -1.1 & -12.6 & -0.9 & -11.1 \\
\hline 2006-2015 & -0.5 & -6.8 & -0.6 & -7.8 \\
\hline 2015-18 & -0.6 & -8.4 & -2.0 & -28.8 \\
\hline $\mathrm{LIA}^{\mathrm{a}-2018}$ & -8.5 & -57.0 & -0.9 & -9.0 \\
\hline
\end{tabular}

${ }^{a}$ Assuming 1925 as the timing of the icefield-wide LIA maximum. bUsing the 1966 outline from the glaciological map (Kjøllmoen 1999; Andreassen, Kjøllmoen et al. 2012). of many other maritime glaciers along the Norwegian coast, which occurred in response to increased winter precipitation and a mass surplus in the late 1980s/early 1990s (Andreassen et al. 2005, 2016; Andreassen et al. 2020; Nesje et al. 2008; Kjøllmoen et al. 2019). Although the available direct mass balance data from Langfjordjøkelen (Kjøllmoen et al. 2019) also show high annual winter balances between 1989 and 1994 (and even slightly positive balance years in 1991/92 and 1992/93), summer ablation was often slightly higher (Fig. 8). This resulted in negative annual balances between 1989 and 1991, and a cumulative mass balance of $-1.4 \mathrm{~m}$ w.e. in the period 1989-1994. The strong recession in the 19942006 period, by contrast, coincides with consistently highly negative balance years between 1997 and 2006 (Fig. 8). By 2006, the cumulative mass balance decreased to $-14.8 \mathrm{~m}$ w.e. In situ frontal position measurements at Langfjordjøkelen East since 1998 show a near-linear annual retreat of the outlet (Fig. 9a) (NVE 2019).

After 2006, icefield recession continued at a slightly lower rate of $8 \% 10 \mathrm{a}^{-1}$, with an areal reduction of $0.5 \mathrm{~km}^{2}$ $(7 \%)$ and a change in average length of $-8.1 \mathrm{~m} \mathrm{a}^{-1}$ between 2006 and 2015. Since then, Langfjordjøkelen's decline has increased dramatically to $29 \% 10 \mathrm{a}^{-1}$, resulting in an area loss of $0.6 \mathrm{~km}^{2}(8 \%)$ in the final measurement period 2015-18. The rate of frontal retreat has risen sharply to $15.1 \mathrm{~m} \mathrm{a}^{-1}$ since 2015 . The varying pace of 21 st-century

Table 4 Changes in length and frontal retreat rates of Langfjordjøkelen's icefield units for each measurement period as well as cumulative glacier length changes since the LIA (1925).

\begin{tabular}{|c|c|c|c|c|c|c|c|c|c|c|c|}
\hline \multirow[t]{2}{*}{ Glacier unit ID } & \multirow[t]{2}{*}{$\begin{array}{l}\text { Informal glacier } \\
\text { unit name }\end{array}$} & \multirow[t]{2}{*}{$\begin{array}{l}\text { LIA centreline } \\
\text { length }(\mathrm{m})\end{array}$} & \multicolumn{7}{|c|}{ Total length change per interval (m) } & \multicolumn{2}{|c|}{$\begin{array}{l}\text { Cumulative length } \\
\text { change LIA-2018 }\end{array}$} \\
\hline & & & 1945 & $1966 a$ & 1988 & 1994 & 2006 & 2015 & 2018 & $\mathrm{~m}$ & $\%$ \\
\hline 49 & LAJ NE & 2354 & -144 & -640 & -579 & +8 & -8 & +7 & -11 & -1367 & -58.1 \\
\hline 50 & & 2046 & -235 & -709 & -19 & +10 & -37 & -9 & -37 & -1036 & -50.6 \\
\hline 51 & & 1817 & -260 & -234 & +22 & -43 & -26 & -66 & $(+68)$ & -607 & -33.4 \\
\hline 52 & LAJ NW & 2325 & -307 & -137 & -101 & -95 & -455 & -38 & $(-773)$ & -1133 & -48.7 \\
\hline 53 & LAJ West & 3082 & -455 & -609 & -46 & -4 & -74 & +27 & +14 & -1147 & -37.2 \\
\hline 54 & LAJ East & 5836 & -391 & -229 & -571 & -102 & -433 & -170 & -118 & -2014 & -34.5 \\
\hline 55 & & 1070 & +4 & $(+244)$ & $(-131)$ & -211 & -45 & -174 & -24 & -450 & -42.1 \\
\hline 56 & & 1544 & -148 & -26 & $(+62)$ & -204 & $(+51)$ & -160 & -95 & -633 & -41.0 \\
\hline Mean ${ }^{b}$ & Langfjordjøkelen & 2509 & -242 & -323 & -162 & -80 & -135 & -73 & -34 & -1048 & -41.8 \\
\hline \multirow{2}{*}{$\begin{array}{l}\text { Mean rate of } \\
\text { change }\left(\mathrm{m} \mathrm{a}^{-1}\right)^{c}\end{array}$} & Langfjordjøkelen & & -12.1 & -17.6 & -9.8 & -13.4 & -12.8 & -8.1 & -15.1 & \multirow{2}{*}{ LIA-2018 $\left(\mathrm{m} \mathrm{a}^{-1}\right)^{c, d}$} & -11.3 \\
\hline & LAJ East (ID 54) & & -19.6 & -10.9 & -26.0 & -17.0 & -36.1 & -18.9 & -39.3 & & -21.7 \\
\hline
\end{tabular}

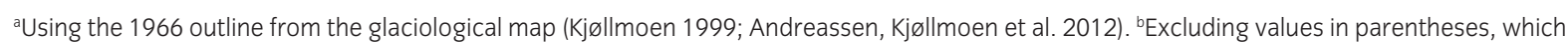
are thought to be erroneous either because of ice-marginal snow or detached glacier parts. 'Assuming 1925 as the timing of the icefield-wide LIA maximum. ${ }^{d} U$ sing the respective cumulative length change values as the basis for the calculations. 


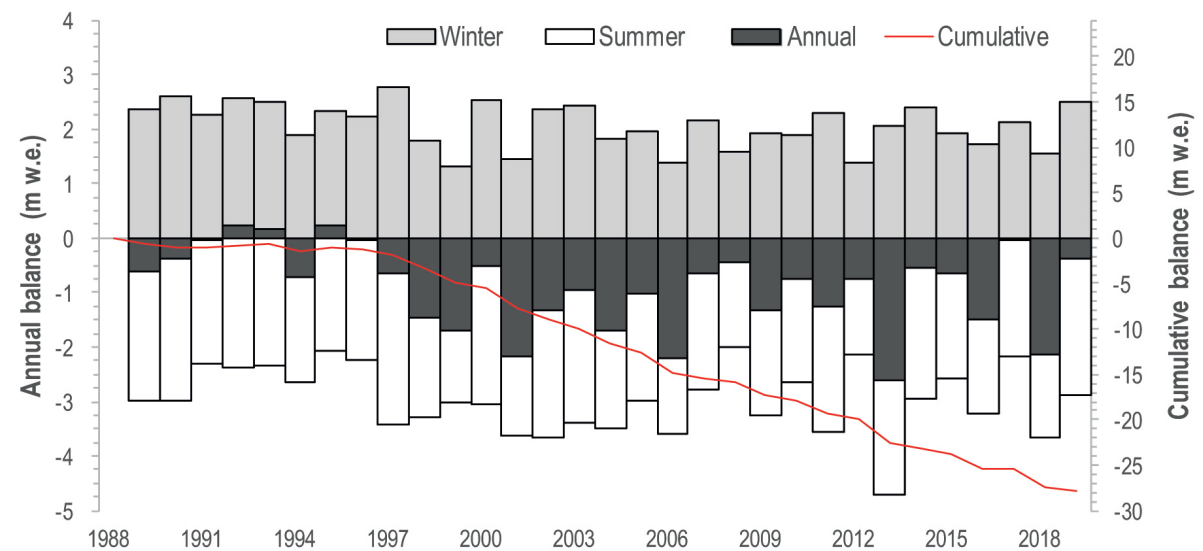

Fig. 8 Mass balance at Langfjordjøkelen for the period 1989-2019 with modelled values for the years 1994 and 1995 (redrawn from Kjøllmoen et al. 2019; data: NVE 2019).

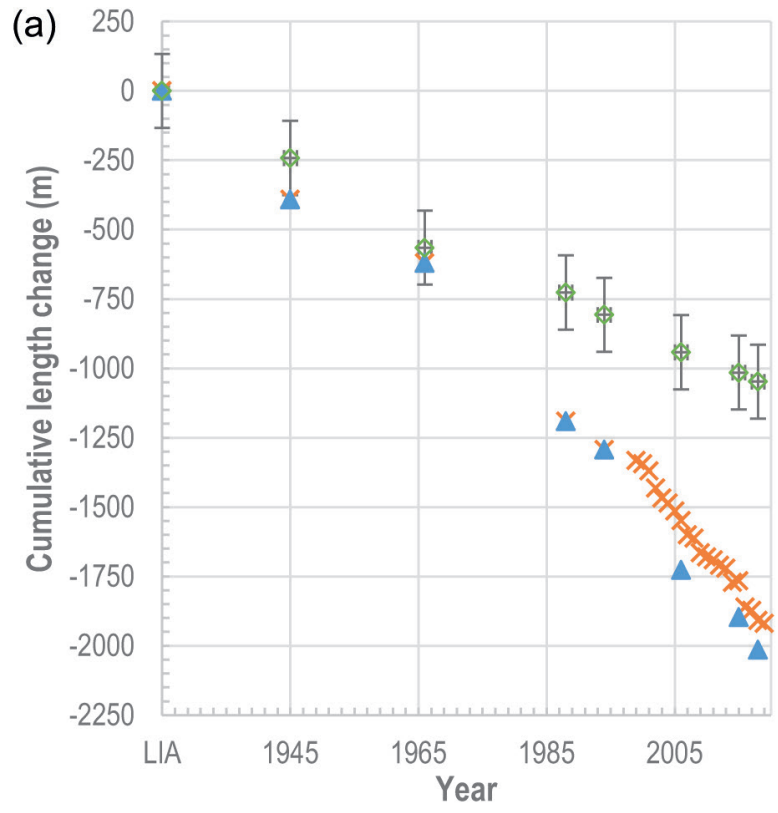

$\begin{array}{ccc}\times \text { LAJ East } / 54 & \Delta \text { LAJ East } / 54 & \text { (remote sensing) }\end{array} \quad$ (remote sensing/ mean (all units)

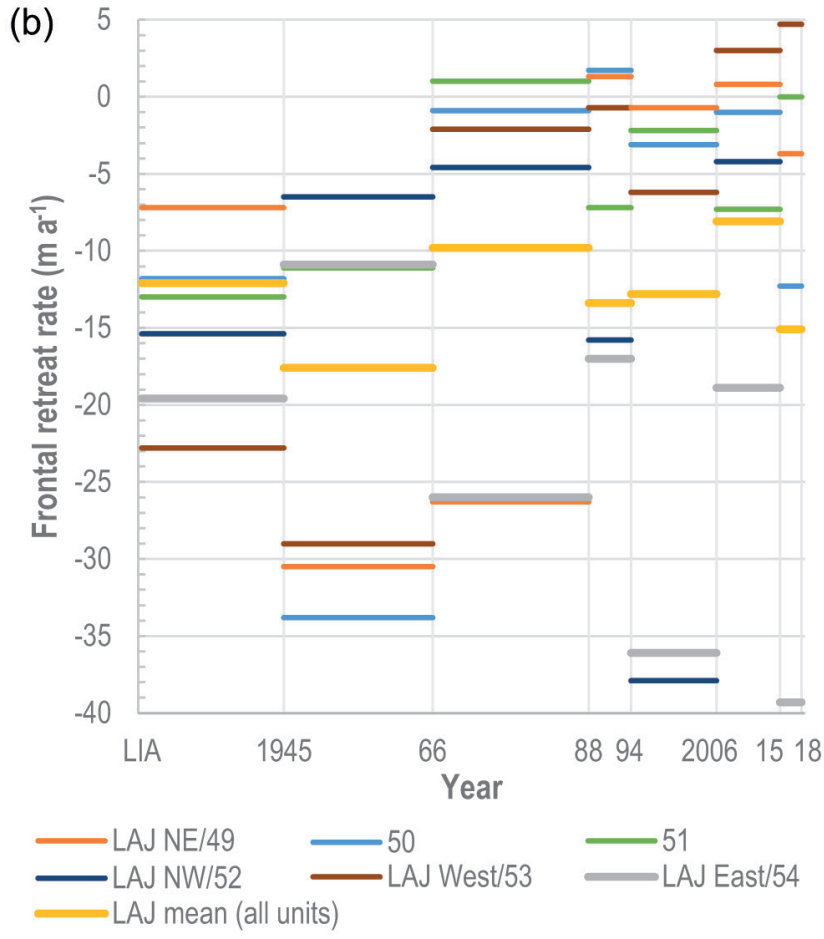

Fig. 9 (a) Cumulative frontal retreat of Langfjordjøkelen (mean of all eight icefield units) and Langfjordjøkelen East. Error bars indicate the standard error. Combined cumulative length change at Langfjordjøkelen East includes remotely sensed values up to 1994 and in situ observations from 1998 to 2019 (NVE 2019). Note how the combined cumulative change is slightly less negative than the cumulative change based on remote-sensing data alone. (b) Rates of frontal retreat at Langfjordjøkelen's major outlet glaciers (excluding the two small plateau-based icefield units 55 and 56 ) since the LIA maximum (1925). Mean values are based on all eight icefield units. Positive values indicating glacier advance are most likely incorrect, probably because of ice-marginal snow included in some of the icefield outlines. Null values indicate that no retreat rate could be calculated.

icefield retreat is not mirrored in Langfjordjøkelen's annual and cumulative mass balance record, which has displayed a steady, and steep, downward trend since 1997, decreasing to $-27.9 \mathrm{~m}$ w.e. in 2019 (Fig. 8) (NVE 2019). Nonetheless, the magnitude of areal shrinkage in the most recent measurement interval is unprecedented, reflecting accelerated regional and global glacier wastage since the end of the 20th century (Vaughan et al. 2013; Zemp et al. 2015; Małecki 2016; Stokes et al. 2018; Weber et al. 2019; Andreassen et al. 2020). 
Over the total measurement period from the LIA (1925) to 2018, Langfjordjøkelen lost an area of $8.5 \mathrm{~km}^{2}$ $(57 \%)$ at a rate of $0.9 \mathrm{~km}^{2} 10 \mathrm{a}^{-1}\left(9 \% 10 \mathrm{a}^{-1}\right)$. The icefield's glacier units decreased in cumulative length by $1.0 \mathrm{~km}$ $\left(42 \% ; 11.3 \mathrm{~m} \mathrm{a}^{-1}\right)$ on average (Fig. 9a). Langfjordjøkelen East retreated by $2.0 \mathrm{~km}(35 \%)$, at a rate of approximately twice the icefield-wide average $\left(21.7 \mathrm{~m} \mathrm{a}^{-1}\right)$ (Fig. 9b). Assuming an LIA maximum in 1905 (based on the uncertainty of \pm 20 years associated with the Wittmeier et al. [2015] LIA age) yields slightly lower rates of icefield change over the total period LIA-2018, with areal shrinkage of $0.7 \mathrm{~km}^{2} 10 \mathrm{a}^{-1}\left(7 \% 10 \mathrm{a}^{-1}\right)$ and a frontal retreat of $9.3 \mathrm{~m} \mathrm{a}^{-1}$ (17.8 $\mathrm{m} \mathrm{a}^{-1}$ at Langfjordjøkelen East).

Glacier area change of the two cirque glaciers of the Áibmadasgáisá massif was assessed for the period 1925-2015, revealing a total area loss of $0.6 \mathrm{~km}^{2}(54 \%)$ at the southern (south-east facing) cirque (ID 59) and $0.8 \mathrm{~km}^{2}(92 \%)$ at the northern (poleward facing) cirque (ID 57/58). Both ice masses receded at an absolute rate of $0.1 \mathrm{~km}^{2} 10 \mathrm{a}^{-1}$, which corresponds to a relative rate of $9 \% 10 \mathrm{a}^{-1}$ at the southern cirque (consistent with the icefield) and $27 \% 10 \mathrm{a}^{-1}$ at the northern cirque. The excessive percentage decrease of the northern cirque is surprising (and difficult to explain), as the north-east is the favoured slope aspect of small glaciers in northern Scandinavia because of the prevailing westerlies and lee effects (Evans 2006). There is also no significant difference in the maximum altitude between the southern (1039 $\mathrm{m}$ a.s.l.) and northern (993 $\mathrm{m}$ a.s.l.; ID 58) cirque glaciers (Andreassen, Winsvold et al. 2012) that might explain the north-south asymmetry in cirque recession. A lower percentage area change of south-east facing glaciers has also been noted by Stokes et al. (2018) on the Lyngen Peninsula, roughly $90 \mathrm{~km}$ south-west of Langfjordjøkelen (Fig. la).

We did not assess glacier change at the Jiehkkejávri ice patch (ca. $0.1 \mathrm{~km}^{2}$ at the LIA maximum). Some ice is still visible on the 1945 aerial photographs, whilst the depression is covered in snow on the 1966 images and ice-free on aerial photographs from the 1990s.

\section{Discussion}

\section{Effect of snow on remotely sensed glacier outlines}

Snow included in remotely sensed glacier outlines can introduce considerable errors in assessments of glacier change (Racoviteanu et al. 2009; Paul et al. 2013), which is highlighted here by the 1966 icefield extent. Two outlines are available for that year (Fig. 10a), both based on the same vertical aerial photographs from 11 July 1966 (Fig. 10b). One outline was directly produced for the purpose of glaciological studies and used by Kjøllmoen (1999) and Andreassen, Kjøllmoen et al. (2012) as well as in this study, whilst the other was produced by the Norwegian Geographical Survey for the 1:50 000 topographic N50 (M711) map series (Fig. 10c; see Table 1). Winsvold et al. (2014) digitized and included the latter outline in their ca. 1960 inventory of Norwegian glaciers. The N50 icefield outline features a number of uncharacteristic, tentacle-shaped branches (Fig. 10a). Visual inspection of the original aerial photographs revealed these branches to be glacier-proximal snow (Fig. 10b). The inclusion of the snow in this outline leads to an overestimation of the 1966 glacier area by $38 \%$ compared to the outline based on the glaciological map. This is significantly higher than the error values estimated by Paul $\&$ Andreassen (2009) (5-10\% for glaciers with an area of $>5 \mathrm{~km}^{2}$ ). Calculating icefield change using the N50 outline would yield an unrealistic area increase of $22 \%$ $\left(2.4 \mathrm{~km}^{2}\right)$ between 1945 and 1966, followed by an abrupt area loss of $31 \%\left(4.2 \mathrm{~km}^{2}\right)$ in the period 1966-1988 (Table 2). This example demonstrates the need to rigorously examine the quality of digital glacier outlines, and the source data they were derived from, prior to detailed glacier change assessments.

\section{Comparison of centennial-scale glacier change across Norway}

The icefield change at Langfjordjøkelen can be compared to existing estimates of long-term glacier change along a latitudinal transect across Norway. At Hardangerjøkulen in southern Norway (Fig. la), where the LIA maximum was significant earlier (ca. 1750; Andersen $\&$ Sollid 1971), data from Weber et al. (2019) show a total reduction in icefield area and average length of $27 \%$ and $18 \%$, respectively, between 1923-29 and 2013. By contrast, data from Langfjordjøkelen reveal a substantially greater loss in icefield area (53\%) and average length $(40 \%)$ in approximately the same period (1925-2015). The Jotunheimen glaciers, about $125 \mathrm{~km}$ north-north-east of Hardangerjøkulen (Fig. la), also experienced an early (18th century) LIA maximum (Matthews 2005). Here, available glacier inventory data from Andreassen et al. (2008) indicate an areal shrinkage of 27\% between 1931-34 and 2003, compared to $50 \%$ in the 1925-2006 period at Langfjordjøkelen. Our comparison suggests that the relative magnitude of long-term glacier change in northernmost mainland Norway was twice that of southern Norwegian glaciers.

Glacier inventory data from Nordland county, northern central Norway (Fig. la) (LIA maximum in about 1750; e.g., Winkler 2003), indicate that the glaciers across 

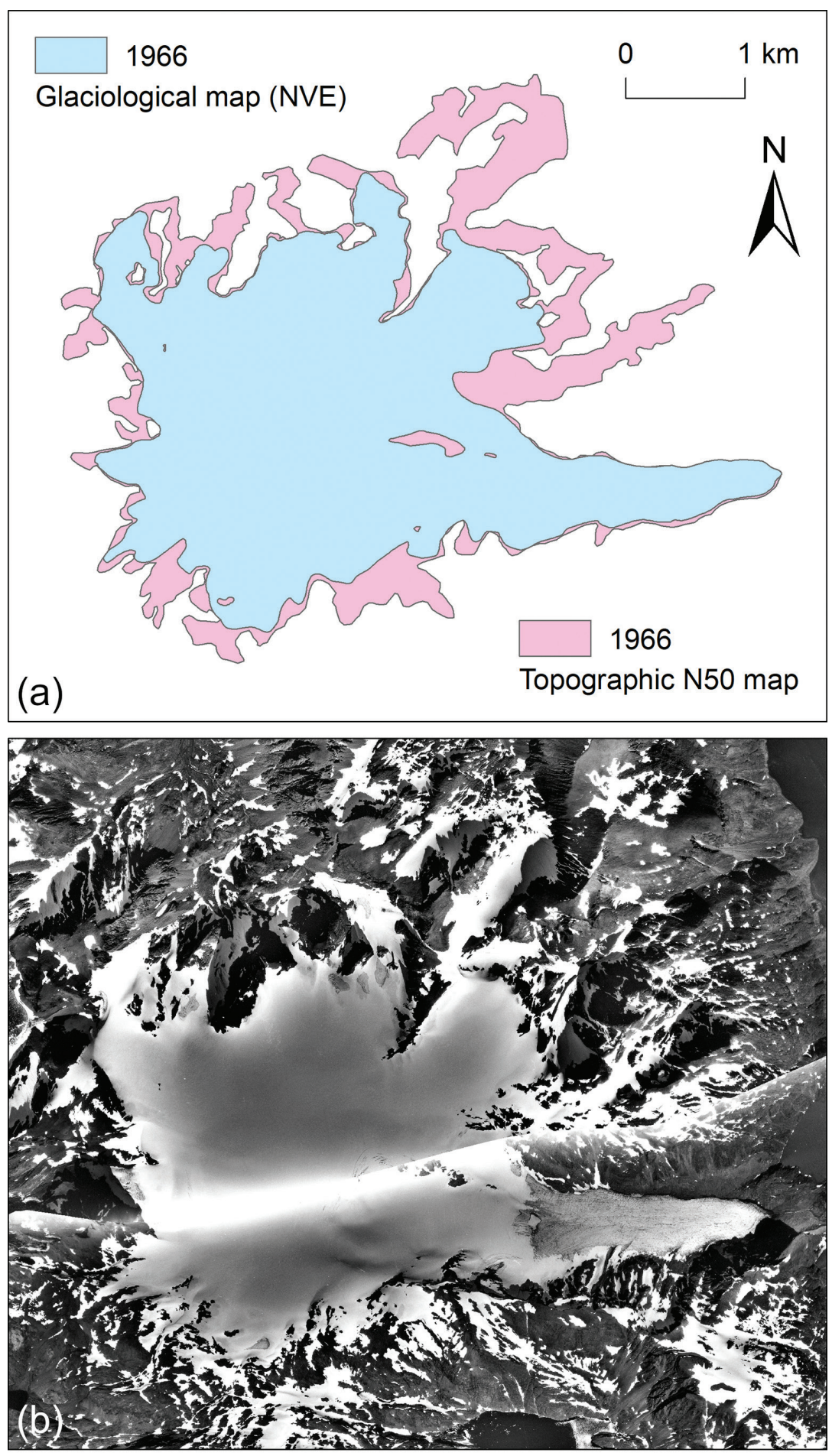

Fig. 10 (Continues next page) (a) Comparison of the two versions of the 1966 icefield extent. Blue: icefield outline as digitized from a glaciological map and used by Kjøllmoen (1999) and Andreassen, Kjøllmoen et al. (2012). Rose-coloured: icefield outline as digitized from the topographic map shown in (c) and used by Winsvold et al. (2014). (b) Georectified vertical aerial photographs of Langfjordjøkelen captured on 11 July 1966 (Sortie: NLF-1800, NLF), which served as the basis for the two icefield outlines shown in (a). (c) Langfjordjøkelen as seen on the (georectified) 1:50 000 topographic N50 (M711) map sheet 1735II Öksfjordjökelen, published by the Norwegian Geographical Survey in 1979. Same extent and scale (1:85 000) in all panels. 


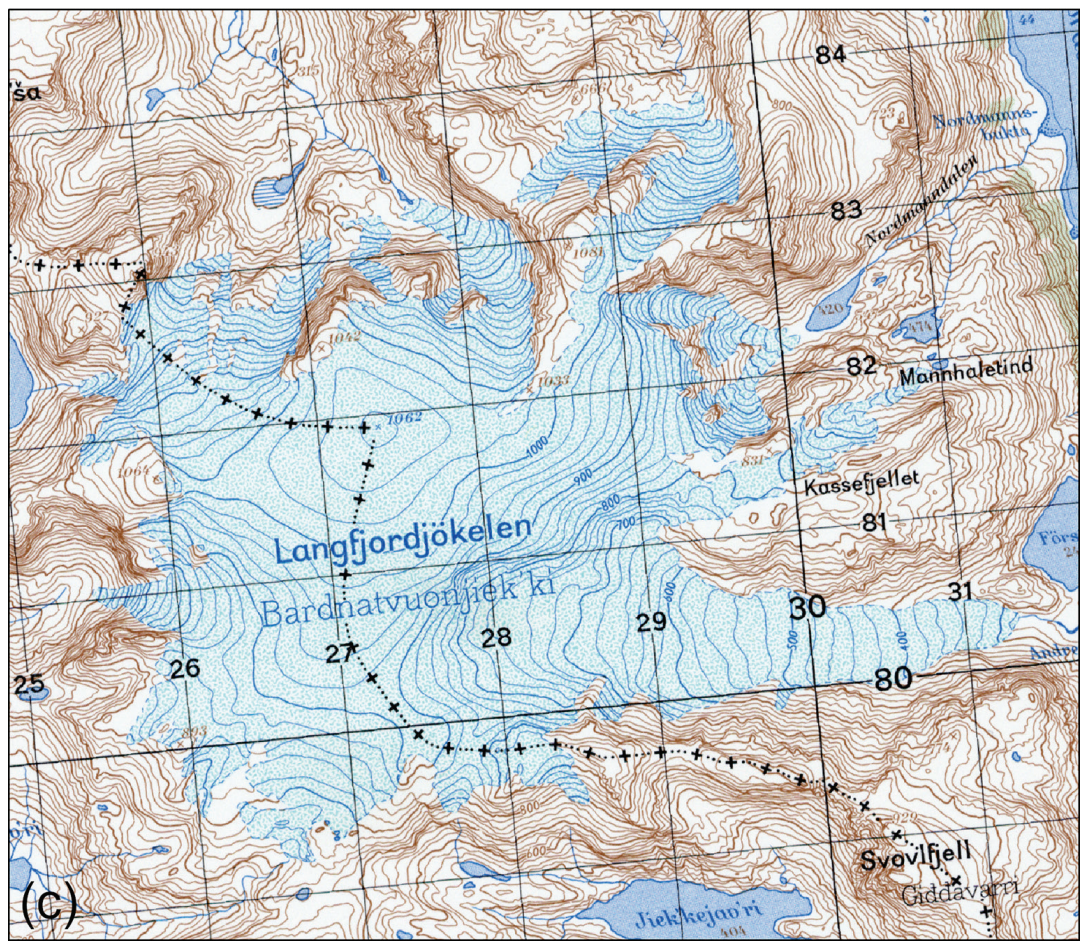

Fig. 10 See caption previous page.

that region receded in area by $47 \%$ between ca. 1899 and 2000 (Weber et al. 2020). This value is similar to Langfjordjøkelen's 50\% area reduction between 1925 and 2006 but represents a considerably longer measurement interval. When icefield-type glaciers were compared alone, the nine largest Nordland icefields decreased in area by only $27 \%$ in the period $1899-2000$ (Weber et al. 2020), which is only about half the percentage change that we observed at Langfjordjøkelen.

Stokes et al. (2018) assessed long-term glacier change in Lyngen since the local LIA maxima in ca. 1750 and ca. 1915 (Ballantyne 1990). They quantified glacier change for several measurement intervals (1750-1915-19531988-2001-2014) but did not calculate overall change from the local LIA to present. In order to allow a general comparison with Langfjordjøkelen, we re-calculated our data to match the Stokes et al. (2018) intervals as closely as possible (areal change for the periods 19251945-1988-2006-2015). Whilst the re-calculated Langfjordjøkelen values for the 20th century are considerably more negative (by factors of between ca. 1.5 to ca. 4.5) than those calculated for Lyngen, initial 21st century glacier recession (2001-2014) was twice as high in Lyngen. Stokes et al. (2018) reported glacier length change in Lyngen only in terms of frontal retreat rates, but not in relative terms (percentage change). A comparison of the Lyngen data our re-calculated retreat rates (again attempting to closely match the Stokes et al. [2018] intervals) revealed no clear pattern; mean frontal retreat since the early 20th century has been consistently high in both areas, with some periods being more negative in Lyngen than at Langfjordjøkelen, and vice versa. The initial 21 st century retreat rates were approximately the same for Lyngen $\left(8.9 \mathrm{~m} \mathrm{a}^{-1}\right.$ between 2001 and 2014) and Langfjordjøkelen (8.1 $\mathrm{m} \mathrm{a}^{-1}$ between 2006 and 2015).

Winsvold et al. (2014) used the historical gradteigskartene maps to also reconstruct glacier change at the four major icefields in the neighbourhood of Langfjordjøkelen (Fig. 1b). Between 1887-1891 and 2006, Øksfjordjøkelen receded in area (A) and length (L) by 21 and 27\%, respectively; Svartfjelljøkelen receded by $46 \%$ (A) and $40 \%$ (L); Seilandsjøkelen (Nuortageašjiehkki) receded by $71 \%$ (A) and $50 \%$ (L); and Nordmannsjøkelen (Dáččavuonjiehkki) receded by $91 \%(\mathrm{~A})$ and $51 \%(\mathrm{~L})$. The comparatively small changes at Øksfjordjøkelen are plausible because the bulk of the icefield is situated on a high-altitude plateau where ablation is limited, with only narrow LIA outlet glaciers descending into confined valleys (Forbes 1853; Geikie 1892; Thoner 1906). Glacier recession at Seilandsjøkelen and Nordmannsjøkelen appears 
to have exceeded even that of Langfjordjøkelen, but we are lacking the data to validate the map-based icefield extents and cannot rule out that the historical mapping is overestimated to a degree similar to that of Langfjordjøkelen.

Centennial-scale glacier length records based on remote sensing and GIS methods, which allow relative (percentage) length change to be calculated, have to date only been established for Hardangerjøkulen (Weber et al. 2019) and the plateau icefields in Finnmark, including Langfjordjøkelen (Winsvold et al. 2014; this study), limiting our comparison. By contrast, long-term records of absolute length change based on in situ frontal position measurements (with $>20$ years of observations) are available for more than 40 Norwegian glaciers, 11 of which have continuous or near-continuous series since the beginning of the 20th century (1899-1905) (Andreassen et al. 2005; NVE 2019). Only Nigardsbreen, Fåbergstølsbreen (both outlet glaciers of Jostedalsbreen; Fig. la) and Engabreen (an outlet glacier of Vestre Svartisen in Nordland; Fig. la) show a stronger cumulative frontal retreat than Langfjordjøkelen East, amounting to approximately $2.6 \mathrm{~km}$ between 1925 and 2019 at all three outlets (Nigardsbreen: $2.9 \mathrm{~km}$ since 1900; Fåbergstølsbreen: 2.7 km since 1899; Engabreen: $2.5 \mathrm{~km}$ since 1903 [NVE 2019]). This makes Langfjordjøkelen East $(2.0 \mathrm{~km})$ still one of the most rapidly retreating glaciers in Norway with available longterm observations. However, when comparing absolute length changes directly, it is worth bearing in mind that the glaciers differ in total sizes and lengths, amongst other factors.

Based on the available data, we conclude that centennial-scale glacier recession in mainland Norway since the early 20th century, specifically in terms of areal shrinkage, has been strongest in the northernmost part of Arctic mainland Norway, supporting the results of Andreassen, Kjøllmoen et al. (2012). An analysis of icefield elevation change for the period 1966-2008 (Andreassen, Kjøllmoen et al. 2012; Andreassen et al. 2020) revealed that Langfjordjøkelen's surface lowered by $30.5 \mathrm{~m}$, equating to an annual geodetic mass balance of $-0.5 \mathrm{~m}$ w.e. These are the most negative values for any Norwegian ice mass (excluding Svalbard) with available surface elevation data in this period $(n=15)$ and double the Norway-wide average $\left(-15.5 \mathrm{~m} ;-0.27 \mathrm{~m}\right.$ w.e. $\mathrm{a}^{-1}$ ) (Andreassen et al. 2020). Surface lowering at Langfjordjøkelen was particularly severe across the glacier tongue of Langfjordjøkelen East, which thinned by more than $100 \mathrm{~m}$ between 1966 and 1994, by up to $73 \mathrm{~m}$ until 2008 and by up to 70 m until 2018 (Andreassen, Kjøllmoen et al. 2012; Kjøllmoen 2019), explaining its extreme backwasting at twice the icefield's mean frontal retreat rate $\left(21.7 \mathrm{~m} \mathrm{a}^{-1}\right)$. The mean AAR at Langfjordjøkelen East has dropped sharply from 45\% in the period 1989-1999 (already significantly below the ca. $60 \%$ threshold to be in balance) to $16 \%$ since 2000 (up to and including the year 2018) (Andreassen, Kjøllmoen et al. 2012; NVE 2019). This shows that a major factor in the strong recession observed at Langfjordjøkelen is that the icefield, and particularly its eastern outlet glacier, lies at altitudes too low to build up any mass (Andreassen, Kjøllmoen et al. 2012; Kjøllmoen 2019). We speculate that the disproportionate warming in this part of Norway (Hanssen-Bauer et al. 2015), possibly influenced by Arctic amplification (e.g., Serreze et al. 2009), controls the high glacier recession rates. Indeed, Andreassen et al. (2020) have shown that, compared to other maritime glaciers in Norway, Langfjordjøkelen's annual mass balance is more dependent on the summer balance, that is to say, variations in summer temperature. There is a strong positive correlation between the mass balance of all maritime glaciers in Norway and the North Atlantic Oscillation (Nesje et al. 2000; Marzeion \& Nesje 2012) and/or the Arctic Oscillation, with the latter correlating highly with Langfjordjøkelen's mass balance (Rasmussen 2007; Andreassen et al. 2020). In their positive phases, both atmospheric circulation patterns lead to increased storminess and precipitation in northern Europe during the winter; therefore, we do not expect that Langfjordjøkelen's accelerated recession is due to differences in the amount of precipitation received. The greater relative importance of the summer balance at Langfjordjøkelen may be the reason why the high precipitation of the late 1980s/early 1990s did not result in a frontal advance, as observed at other maritime glaciers in Norway, but was cancelled out by summer ablation instead (Fig. 8). Overall, we suggest that Langfjordjøkelen's area and volume distribution at critically low altitudes makes it prone to disappear completely in the future under continued Arctic warming (IPCC 2014).

\section{Conclusion}

We present a reconstruction of the ca. 1925 maximum LIA extent of Langfjordjøkelen, a plateau icefield in the northernmost part of Arctic mainland Norway. In addition to Langfjordjøkelen's main eastern outlet glacier, which was considerably more extensive at the LIA maximum, major icefield outlets also existed in the north and west of the plateau. These have retreated entirely onto the plateau summit since the LIA. A historical map of Langfjordjøkelen from 1891 to 1902 is shown to have overestimated the southern icefield extent because of erroneous mapping of snow cover as glacier ice, and therefore cannot be employed in glacier change assessments. Since 
the LIA, the icefield has been in continuous retreat at variable, but consistently negative, rates. By 2018, Langfjordjøkelen had lost $57 \%\left(8.5 \mathrm{~km}^{2}\right)$ of its original LIA area, at a rate of $9 \%\left(0.9 \mathrm{~km}^{2}\right)$ per decade, and its icefield units had receded by $42 \%(1.0 \mathrm{~km})$ on average, at a mean annual rate of $11.3 \mathrm{~m}$. The observed percentage area loss is greater than that of any other Norwegian ice mass (excluding Svalbard) with available and comparable longterm glacier change data and may be ascribed to amplified glacier decline at high latitudes due to enhanced warming trends in the Arctic.

\section{Acknowledgements}

The authors thank Bjarne Kjøllmoen (NVE) for sharing his knowledge and expertise on Langfjordjøkelen and for providing logistical and technical support. They also thank Samuel Chandler for field assistance in 2017. Etienne Berthier kindly provided the Pléiades orthoimagery used to digitize the 2018 icefield extent. The manuscript benefited from constructive comments by Atle Nesje and an anonymous reviewer. This work is also a contribution to the Copernicus Glacier Service Norway project (Copernicus bretjeneste; contract NIT.06.15.5).

\section{Authors' contributions}

PW was responsible for conceptualization, funding acquisition, methodology, field and GIS investigation, analysis, writing of the original draft and figure preparation. $\mathrm{HL}$ and $\mathrm{CMB}$ were responsible for conceptualization, funding acquisition, review and editing of the original draft, and supervision of the study. LMA contributed towards 2018 icefield outline digitization, review and editing of the original draft, and supervision of the study.

\section{Funding}

Fieldwork at Langfjordjøkelen was supported by a Quaternary Research Association New Research Workers' Award and a Royal Geographical Society Postgraduate Research Award.

\section{Data availability}

The LIA, 1945 and 2015 icefield outlines produced by this study are available for download at https://www. nve.no/glacier/, along with previously published icefield outlines.

\section{Disclosure statement}

The authors report no potential conflict of interest.

\section{References}

Allen M.R., Dube O.P., Solecki W., Aragón-Durand F., Cramer W., Humphreys S., Kainuma M., Kala J., Mahowald N., Mulugetta Y., Perez R., Wairiu M. \& Zickfeld K. 2018. Framing and context. In V. Masson-Delmotte et al. (eds.): Global warming of $1.5^{\circ} \mathrm{C}$. Pp. 49-91. Geneva: IPCC.

Andersen J.L. \& Sollid J.L. 1971. Glacial chronology and glacial geomorphology in the marginal zones of the glaciers, Midtdalsbreen and Nigardsbreen, south Norway. Norwegian Journal of Geography 25, 1-38, doi: 10.1080/00291957108551908.

Andreassen L.M., Elvehøy H., Kjøllmoen B. \& Belart J.M.C. 2020. Glacier change in Norway since the 1960s-an overview of mass balance, area, length and surface elevation changes. Journal of Glaciology 66, 313-328, doi: 10.1017/ jog.2020.10.

Andreassen L.M., Elvehøy H., Kjøllmoen B. \& Engeset R.V. 2005. Glacier mass-balance and length variation in Norway. Annals of Glaciology 42, 317-325, doi: 10.3189/17275 6405781812826.

Andreassen L.M., Elvehøy H., Kjøllmoen B. \& Engeset R.V. 2016. Reanalysis of long-term series of glaciological and geodetic mass balance for 10 Norwegian glaciers. The Cryosphere 10, 535-552, doi: 10.5194/tc-10-535-2016.

Andreassen L.M., Kjøllmoen B., Rasmussen A., Melvold K. \& Nordli Ø. 2012. Langfjordjøkelen, a rapidly shrinking glacier in northern Norway. Journal of Glaciology 58, 581-593, doi: 10.3189/2012JoG1 1J014.

Andreassen L.M., Paul F., Kääb A. \& Hausberg J.E. 2008. Landsat-derived glacier inventory for Jotunheimen, Norway, and deduced glacier changes since the 1930s. The Cryosphere 2, 131-145, doi: 10.5194/tc-2-131-2008.

Andreassen L.M., Winsvold S.H., Paul F. \& Hausberg J.E. 2012. Inventory of Norwegian glaciers. NVE Rapport 2012:38. Oslo: NVE.

Bakke J., Dahl S.O., Paasche Ø., Løvlie R. \& Nesje A. 2005. Glacier fluctuations, equilibrium-line altitudes and palaeoclimate in Lyngen, northern Norway, during the Lateglacial and Holocene. The Holocene 15, 518-540, doi: 10.1191/0959683605hl815rp.

Ballantyne C.K. 1990. The Holocene glacial history of Lyngshalvöya, northern Norway: chronology and climatic implications. Boreas 19, 93-117, doi: 10.1111/j.1502-3885. 1990.tb00570.x.

Baumann S., Winkler S. \& Andreassen L.M. 2009. Mapping glaciers in Jotunheimen, South-Norway, during the "Little Ice Age" maximum. The Cryosphere 3, 231-243, doi: 10.5194/tc-3-231-2009.

Bickerton R.W. \& Matthews J.A. 1993. "Little Ice Age" variations of outlet glaciers from the Jostedalsbreen icecap, southern Norway: a regional lichenometric-dating study of ice-marginal moraine sequences and their 
climatic significance. Journal of Quaternary Science 8, 45-66, doi: 10.1002/jqs.3390080105.

Box J.E., Colgan W.T., Christensen T.R., Schmidt N.M., Lund M., Parmentier F.-J.W., Brown R., Bhatt U.S., Euskirchen E.S., Romanovsky V.E., Walsh J.E., Overland J.E., Wang M., Corell R.W., Meier W.N., Wouters B., Mernild S., Mård J., Pawlak J. \& Skovgård Olsen M. 2019. Key indicators of Arctic climate change: 1971-2017. Environmental Research Letters 14, article no. 045010, doi: 10.1088/1748-9326/ aafclb.

Box J.E., Colgan W.T., Wouters B., Burgess D.O., O'Neel S., Thomson L.I. \& Mernild S.H. 2018. Global sealevel contribution from Arctic land ice: 1971-2017. Environmental Research Letters 13, article no. 125012, doi: 10.1088/1748-9326/aaf2ed.

Bush E. \& Lemmen D.S. (eds.) 2019. Canada's changing climate report. Ottawa: Government of Canada.

Chandler B.M.P., Lovell H., Boston C.M., Lukas S., Barr I.D., Benediktsson Í.Ö., Benn D.I., Clark C.D., Darvill C.M., Evans D.J.A., Ewertowski M.W., Loibl D., Margold M., Otto J.-C., Roberts D.H., Stokes C.R., Storrar R.D. \& Stroeven A.P. 2018. Glacial geomorphological mapping: a review of approaches and frameworks for best practice. Earth-Science Reviews 185, 806-846, doi: 10.1016/j. earscirev.2018.07.015.

Erikstad L. \& Sollid J.L. 1986. Neoglaciation in south Norway using lichenometric methods. Norwegian Journal of Geography 40, 85-105, doi: 10.1080/00291958608552159.

Evans D.J., Rea B.R., Hansom J.D. \& Whalley W.B. 2002. Geomorphology and style of plateau icefield deglaciation in fjord terrains: the example of Troms-Finnmark, north Norway. Journal of Quaternary Science 17, 221-239, doi: 10.1002/jqs.675.

Evans I.S. 2006. Local aspect asymmetry of mountain glaciation: a global survey of consistency of favoured directions for glacier numbers and altitudes. Geomorphology 73, 166-184, doi: 10.1016/j.geomorph.2005.07.009.

Forbes J.D. 1853. Norway and its glaciers. Visited in 1851. Edinburgh: A. and C. Black.

Geikie A. 1892. Geological sketches. At home and abroad. New York: Macmillan and Co.

Grove J.M. 2004. Little ice ages: ancient and modern. London: Routledge.

Hanssen-Bauer I. 2005. Regional temperature and precipitation series for Norway: analyses of time-series updated to 2004. MET Report 15/2005. Oslo: Meteorological Institute.

Hanssen-Bauer I., Førland E.J., Haddeland I., Hisdal H., Mayer S., Nesje A., Nilsen J.E.Ø., Sandven S., Sandø A.B., Sorteberg A. \& Ådlandsvik B. (eds.) 2015. Klima i Norge 2100. (Climate in Norway 2100.) NCCS report 2/2015. Oslo: Norwegian Environment Agency.

Hanssen-Bauer I., Førland E.J., Hisdal H., Mayer S., Sandø A.B. \& Sorteberg A. 2019. Climate in Svalbard 2100. NCCS Report 1/2019. Oslo: Norwegian Environment Agency.

Hardy J.F. 1862. The Jökuls glacier. In E.S. Kennedy (ed.): Peaks, passes, and glaciers: being excursions by members of the Alpine club. Second series. Pp. 429-441. London: Longman, Green, Longman, and Roberts.
Hegerl G.C., Brönnimann S., Schurer A. \& Cowan T. 2018. The Early 20th Century Warming: anomalies, causes, and consequences. WIREs Climate Change 9, e522, doi: 10.1002/ WCC. 522 .

Hoel A. \& Werenskiold W. 1962. Glaciers and snowfields in Norway. Norsk Polarinstitutt Skrifter 114. Oslo: Norwegian Polar Institute.

IPCC 2014. Climate change 2014: synthesis report. Contribution of Working Groups I, II and III to the fifth assessment report of the Intergovernmental Panel on Climate Change. Core Writing Team, R.K. Pachauri \& L.A. Meyer (eds.). Geneva: IPCC.

Kjøllmoen B. 1999. Breundersøkelser på Langfjordjøkelen 1998. (Glacier investigations at Langfjordjøkelen 1998.) NVE Dokument 1999:2. Oslo: NVE.

Kjøllmoen B. 2019. Reanalysing a glacier mass balance measurement series-Langfjordjøkelen 2008-2018. NVE Rapport 2019:48. Oslo: NVE.

Kjøllmoen B., Andreassen L.M., Elvehøy H. \& Jackson M. 2019. Glaciological investigations in Norway 2018. NVE Rapport 2019:46. Oslo: NVE.

Małecki J. 2016. Accelerating retreat and high-elevation thinning of glaciers in central Spitsbergen. The Cryosphere 10, 1317-1329, doi: 10.5194/tc-10-1317-2016.

Marzeion B. \& Nesje A. 2012. Spatial patterns of North Atlantic Oscillation influence on mass balance variability of European glaciers. The Cryosphere 6, 661-673, doi: 10.5194/tc-6-661-2012.

Matthews J.A. 2005. "Little Ice Age" glacier variations in Jotunheimen, southern Norway: a study in regionally controlled lichenometric dating of recessional moraines with implications for climate and lichen growth rates. The Holocene 15, 1-19, doi: 10.1191/0959683605hl779rp.

Meredith M., Sommerkorn M., Cassotta S., Derksen C., Ekaykin A., Hollowed A., Kofinas G., Mackintosh A., Melbourne-Thomas J., Muelbert M.M.C., Ottersen G., Pritchard H. \& Schuur E.A.G. 2019. Polar regions. In H.-O. Pörtner et al. (eds.): The ocean and cryosphere in a changing climate. A special report of the Intergovernmental Panel on Climate Change. Pp. 203-320. Geneva: IPCC.

Nesje A., Bakke J., Dahl S.O., Lie Ø. \& Matthews J.A. 2008. Norwegian mountain glaciers in the past, present and future. Global and Planetary Change 60, 10-27, doi: 10.1016/j.gloplacha.2006.08.004.

Nesje A., Lie Ø. \& Dahl S.O. 2000. Is the North Atlantic Oscillation reflected in Scandinavian glacier mass balance records? Journal of Quaternary Science 15, 587-601, doi: 10.1002/1099-1417(200009) 15:6<587::AIDJQS533>3.0.CO;2-2.

NVE 2019. Climate indicator products. Accessed on the internet at http://glacier.nve.no/glacier/viewer/ci/en/ on 31 December 2019

Paul F. \& Andreassen L.M. 2009. A new glacier inventory for the Svartisen region, Norway, from Landsat ETM+ data: challenges and change assessment. Journal of Glaciology 55, 607-618, doi: 10.3189/002214309789471003.

Paul F., Barrand N.E., Baumann S., Berthier E., Bolch T., Casey K., Frey H., Joshi S.P., Konovalov V., Le Bris R., Mölg N., Nosenko G., Nuth C., Pope A., Racoviteanu A.E., 
Rastner P., Raup B., Scharrer K., Steffen S. \& Winsvold S.H. 2013. Challenges and recommendations in mapping of glacier parameters from space: results of the 2008 Global Land Ice Measurements from Space (GLIMS) workshop, Boulder, Colorado, USA. Annals of Glaciology 54, 171-182, doi: 10.3189/2013AoG63A296.

Racoviteanu A.E., Paul F., Raup B., Khalsa S.J.S. \& Armstrong R. 2009. Challenges and recommendations in mapping of glacier parameters from space: results of the 2008 Global Land Ice Measurements from Space (GLIMS) workshop, Boulder, Colorado, USA. Annals of Glaciology 50, 53-69, doi: 10.3189/172756410790595804.

Rasmussen L.A. 2007. Spatial extent of influence on glacier mass balance of North Atlantic circulation indices. Terra Glacialis 10, 43-58.

Serreze M.C., Barrett A.P., Stroeve J.C., Kindig D.N. \& Holland M.M. 2009. The emergence of surface-based Arctic amplification. The Cryosphere 3, 11-19, doi: 10.5194/ tc-3-11-2009.

Stokes C.R., Andreassen L.M., Champion M.R. \& Corner G.D. 2018. Widespread and accelerating glacier retreat on the Lyngen Peninsula, northern Norway, since their "Little Ice Age" maximum. Journal of Glaciology 64, 100-118, doi: 10.1017/jog.2018.3.

Thoner J. 1906. Fra Alnas Njarggas fjorde og jøkler. (From Alnas Njargga's fjords and glaciers.) Den Norske Turistforenings Aarbok 1906, 71-88.

Tvede A.M. 1973. Folgefonni-en glasiologisk avviker. (Folgefonni-a glaciological anomaly.) Naturen 97, 11-16.

Vaughan D.G., Comiso J.C., Allison I., Carrasco J., Kaser G., Kwok R., Mote P., Murray T., Paul F., Ren J., Rignot E., Solomina O., Steffen K. \& Zhang T. 2013. Observations: cryosphere. In Stocker et al. (eds.): Climate change 2013: the physical science basis. Contribution of Working Group I to the fifth assessment report of the Intergovernmental Panel on Climate Change. Pp. 317-382. Cambridge: Cambridge University Press.

Whalley W.B. \& Kjøllmoen B. 2000. Øksfjord and Seiland. In L.M. Andreassen (ed.): Regional change of glaciers in northern Norway. NVE Report 2000:1. Pp. 96-113. Oslo: NVE.

Weber P., Andreassen L.M., Boston C.M., Lovell H. \& Kvarteig S. 2020. An 1899 glacier inventory for Nordland, northern Norway, produced from historical maps. Journal of Glaciology 66, 259-277, doi: 10.1017/jog.2020.3.
Weber P., Boston C.M., Lovell H. \& Andreassen L.M. 2019. Evolution of the Norwegian plateau icefield Hardangerjøkulen since the "Little Ice Age". The Holocene 29, 1885-1905, doi: 10.1177/0959683619865601.

Winkler S. 2003. A new interpretation of the date of the "Little Ice Age" glacier maximum at Svartisen and Okstindan, northern Norway. The Holocene 13, 83-95, doi: 10.1191/0959683603hl573rp.

Winsvold S.H., Andreassen L.M. \& Kienholz C. 2014. Glacier area and length changes in Norway from repeat inventories. The Cryosphere 8, 1885-1903, doi: 10.5194/tc-8-1885-2014.

Wittmeier H.E., Bakke J., Vasskog K. \& Trachseld M. 2015. Reconstructing Holocene glacier activity at Langfjordjøkelen, Arctic Norway, using multi-proxy fingerprinting of distal glacier-fed lake sediments. Quaternary Science Reviews 114, 78-99, doi: 10.1016/j.quascirev.2015.02.007.

WMO 2019. WMO Statement on the state of the global climate in 2018. Geneva: WMO.

Zemp M., Armstrong R., Gärtner-Roer I., Haeberli W., Hoelzle M., Kääb A., Kargel J.S., Khalsa S.J.S., Leonard G.J., Paul F. \& Raup B.H. 2014. Introduction: global glacier monitoring-a long-term task integrating in situ observations and remote sensing. In J. Kargel et al. (eds.): Global land ice measurements from space. Pp. 1-21. Berlin: Springer, doi: 10.1007/978-3-540-79818-7_1.

Zemp M., Frey H., Gärtner-Roer I., Nussbaumer S.U., Hoelzle M., Paul F., Haeberli W., Denzinger F., Ahlstrøm A.P., Anderson B., Bajracharya S., Baroni C., Braun L.N., Cáceres B.E., Casassa G., Cobos G., Dávila L.R., Granados H.D., Demuth M.N., Espizua L., Fischer A., Fujita K., Gadek B., Ghazanfar A., Hagen J.O., Holmlund P., Karimi N., Li Z., Pelto M., Pitte P., Popovnin V.V., Portocarrero C.A., Prinz R., Sangewar C.V., Severskiy I., Sigurđsson O., Soruco A., Usubaliev R. \& Vincent C. 2015. Historically unprecedented global glacier decline in the early 21 st century. Journal of Glaciology 61, 745-762, doi: 10.3189/2015JoG15J017.

Zemp M., Huss M., Thibert E., Eckert N., McNabb R., Huber J., Barandun M., Machguth H., Nussbaumer S.U., Gärtner-Roer I., Thomson L., Paul F., Maussion F., Kutuzov S. \& Cogley J.G. 2019. Global glacier mass changes and their contributions to sea-level rise from 1961 to 2016. Nature 568, 382-386, doi: 10.1038/s41586-019-1071-0. 